\title{
We're All in This Together: Legitimacy and Coronavirus-Oriented CSR Messaging
}

\author{
Nicholas Browning *, Ejae Lee $\mathbb{D}^{\mathbb{C}}$, Sung Hyun Lee and Sung-Un Yang \\ The Media School, Indiana University, Bloomington, IN 47405, USA; ejaelee@indiana.edu (E.L.); \\ sunghlee@iu.edu (S.H.L.); yang223@indiana.edu (S.-U.Y.) \\ * Correspondence: nickphd@indiana.edu
}

Citation: Browning, N.; Lee, E.; Lee, S.H.; Yang, S.-U. We're All in This Together: Legitimacy and Coronavirus-Oriented CSR Messaging. Sustainability 2022, 14, 2534. https://doi.org/10.3390/ su14052534

Academic Editors: Hyejoon Rim and Holly Overton

Received: 26 January 2022

Accepted: 17 February 2022

Published: 22 February 2022

Publisher's Note: MDPI stays neutral with regard to jurisdictional claims in published maps and institutional affiliations.

Copyright: (C) 2022 by the authors. Licensee MDPI, Basel, Switzerland. This article is an open access article distributed under the terms and conditions of the Creative Commons Attribution (CC BY) license (https:// creativecommons.org/licenses/by/ $4.0 /)$.
Abstract: This study investigates how legitimization strategies embedded in CSR messages related to the COVID-19 pandemic influenced multidimensional stakeholder assessments of reputation. The results of this $3 \times 2 \times 2$ experimental survey, which manipulated pragmatic and moral legitimacy using three conditions (self- vs. other- vs. both-oriented messaging); substantive and symbolic management (informative vs. uninformative content); and popularization and standardization approaches (leadership vs. followership), indicate that popularization strategies communicated substantively and standardization strategies communicated symbolically generally yield the greatest reputational gains. More nuanced findings from three-way interaction effects are further discussed, with an emphasis on the role of double-sided messages seeking to simultaneously establish pragmatic and moral legitimacy.

Keywords: public relations; legitimacy; corporate social responsibility (CSR); reputation management; COVID-19

\section{Introduction}

In the most basic terms, legitimacy represents correspondence among organizational and societal values [1-3]. Legitimacy gaps occur when incongruencies emerge, most typically when organizational actions fail to meet societal expectations [4-6]. While there are a number of reasons why such chasms arise, the dynamic quality of legitimacy is of greatest concern here. Societal norms invariably change, forcing organizations to adapt to maintain at least the perception of alignment between their actions and societal expectations [1,7].

While norms and values are in near constant states of flux, certain flashpoint events can create extreme change at unprecedented speed. The COVID-19 pandemic represents one such flashpoint, leading to upheaval across numerous business sectors and facets of daily life on a global scale and at a breakneck pace.

From a pragmatic, bottom-line perspective, COVID-19 has been disastrous. Global supply chains were thrust into disarray as demand collapsed, then later outpaced supply [8-10]. Employment followed a similarly chaotic pattern. In the U.S. millions lost their jobs and millions more transitioned to telework [11]. As restrictions eased, labor shortages resulted, particularly in hospitality industries [12]. As of early 2022, these patterns showed few signs of slowing, with waves of workers across various sectors reflecting on their expectations from employers, and many opting to exit during a continuing 'Great Resignation' [13-16].

These practical challenges have given way to moral ones. Social debates raged as to employers' responsibilities in safeguarding their workers [17], which later morphed into the question of whether employers can or should mandate vaccinations for their workforce [18,19]. Additionally, unemployment relief afforded many laborers significant negotiating leverage for the first time in a generation, fueling fights for increased wages and benefits $[11,20]$. 
Against this backdrop, organizations flooded the public with corporate social responsibility (CSR) messaging, the presumed goal of which was to instill in various stakeholders a sense that these companies indeed had the public's best interest at heart. In short, these efforts represent efforts to legitimize organizational responses to the pandemic, with varying degrees of appeal to pragmatic and moral considerations.

While scholars have argued CSR should lead to improved organizational reputation resulting from enhanced legitimacy [21-23], much of the empirical research connecting CSR and legitimacy has focused on back-end CSR reporting and disclosures [2,5,24,25], with comparatively little scholarship exploring the antecedent characteristics of CSR messaging that might also engender legitimacy. The purpose of this study is to experimentally investigate whether and how varying legitimization strategies embedded in CSR messaging characteristics influence reputational gains in specific domains. In particular, this study investigates the use of message sidedness in highlighting certain types of legitimacy; the substantive efforts or symbolic gestures used in messaging; the role of sector leadership compared with isomorphic tactics; and the potential interaction effects of these constructs in linking legitimacy to numerous subdimensions of reputation.

\section{What Is Legitimacy?}

\subsection{Definition and Characteristics}

Legitimacy is an oft-discussed yet difficult-to-measure construct. Suchman's [3] work is perhaps the most heavily relied upon in PR literature, and we adoppt his operational definition: "Legitimacy is a generalized perception or assumption that the actions of an entity are desirable, proper, or appropriate within some socially constructed system of norms, values, beliefs, and definitions" (p. 574, emphasis original). Scholars regard legitimacy as an operational resource that, at its heart, guarantees organizations a so-called 'license to operate,' which provides the base level of leeway necessary for an organization to flourish $[1,3,4,26,27]$.

Unpacking that definition further reveals key characteristics of the construct. First, legitimacy constitutes a perceived judgment as to whether organizational goals and actions align with some value system. Stakeholders make these judgments, and "like beauty, it resides in the eye of the beholder" [28] (p. 177). Because legitimacy is determined not by the organization but rather by engaged constituencies, managing it is inherently difficult. However, that difficulty multiplies exponentially when one considers that stakeholders define and assess legitimacy in a myriad of ways, which becomes further complicated considering the power imbalances among stakeholders [24]:

"In practice it is to be expected that organizations have a series of social contracts with various stakeholder groups and that the importance of compliance with particular 'contracts' is in part be dependent upon the 'power' of the respective stakeholder groups." [4] (p. 171)

Therefore, one might more accurately claim that organizations must manage various and at times conflicting legitimacies rather a single, overarching perception.

Generally speaking, past research has consistently shown that maintaining legitimacy is much easier than initially gaining or repairing it. As such, legitimacy possesses somewhat of an inertial quality $[3,4,28]$. Nevertheless, once established, legitimacy is not forever guaranteed. Sawyer, Johnson, and Holub [6] argued that when "significant differences develop between the value systems of the organization and its conferring entities, conferring entities with power can threaten the organization's legitimacy by the use of legal, economic and/or social sanctions" (p. 88).

These differences constitute legitimacy gaps, and while organizations can create these gaps through abrupt policy changes, the dynamic nature of norms, values, and beliefs present greater challenges. Societies are fluid, and when norms change, organizations must adjust to maintain the legitimacy connected with congruent behaviors $[1,7,29]$. Failing to monitor stakeholder expectations and adapt accordingly represent perhaps the most significant challenges to organizational legitimacy. 


\subsection{Distinguishing Legitimacy Forms}

As distinct stakeholder groups make disparate judgments about legitimacy, they also make judgments about different facets of an organization, potentially conferring distinct types of legitimacy. Again, Suchman's [3] typology proves informative here, and his work echoes, and has been echoed, by that of numerous legitimacy scholars (e.g., $[1,2,6,28,30])$.

Suchman [3] described three general types of legitimacy: pragmatic, moral, and cognitive. Pragmatic legitimacy is rooted in the self-interests of both the organization and its audiences. It largely reflects a stakeholder perception that an organization has effectively delivered on instrumental expectations, most commonly in the exchanges of goods and services.

Moral legitimacy involves an evaluation of whether an organization supports or undercuts societal welfare within a given value system. The evaluation criteria might be consequentialist (organization accomplishes desirable ends), procedural (organization follows accepted rules of conduct), structural (organization is systemically constructed to promote just action), or personal (organization and its leaders display charisma and character). These four criteria align with major programs of Western ethical thought: utilitarianism, deontology, Rawlsian justice as fairness, and Aristotelean virtue, respectively [31].

Lastly, there is cognitive legitimacy, which embodies the inertial characteristic of legitimacy. At this stage, organizational actions are highly comprehensible and readily explained by easily accessible cultural norms. This creates a taken-for-granted legitimacy in which the very expectation that an organization characteristically behaves legitimately confers legitimacy to its current and future actions $[3,30]$.

\section{Theoretical Considerations for Attaining and Maintaining Legitimacy}

\subsection{Legitimacy Theory}

While Suchman's [3] legitimacy typology helps us understand the various facets of the construct, it would be a mistake to consider each as wholly isolated. As Gray, Kouhy and Lavers [24] argued, "the economic domain cannot be studied in isolation from the political, social and institutional framework within which the economic takes place" (p. 52). As such, the pragmatic legitimacy that results from satisfactory economic exchanges likely impactsand is impacted by—an organization's ability to attain moral legitimacy by adhering to sociopolitical norms.

In fact, adherence to these norms is at the heart of legitimacy theory. According to this theory, organizations have no inherent rights to resources, or even to exist. They exist only with societal approval [26,32]. That approval, or legitimacy, is conferred when organizations comply with the unwritten values and norms of society that comprise the social contract $[4,26,33,34]$.

This contractarian approach is based in the works of Enlightenment philosophers, particularly Thomas Hobbes, John Locke, and Jean-Jacque Rousseau. It recognizes that businesses have an important role to play in providing social as well as economic goods, particularly in an age of globalism in which corporate power and influence rivals that of many nation-states [35-41]. Specifically, to adhere to the social contract requires organizations to "comply with societal expectations and norms while they conduct their operations," while simultaneously ensuring "their activities are perceived to be commensurate with the societal expectations of various stakeholder groups" [42] (p. 2466).

While the social contract basis is valuable, legitimacy theory itself is relatively thin and underdeveloped [26,33]. However, it does present a valuable umbrella under which to elucidate a more complete theoretical scaffolding that explains and predicts how legitimacy is attained and maintained, largely because legitimacy theory overlaps with other prominent theoretical approaches [4].

\subsection{Expectancy Violations Theory}

Expectancy violations theory (EVT) is one such overlap. EVT argues that individuals expect "an enduring pattern of anticipated behavior" from others [43] (p. 31), and that vio- 
lating these expectations triggers a host of potential responses [44]. Responses vary based on violation valence (whether the deviation is viewed as positive or negative), violation magnitude (the extent of the deviation), and reward valence (how gratifying an interaction is and the other party's capacity to bestow future rewards/punishments), such that deviating from an expected behavior can produce net positive or negative reactions [45].

Though Burgoon [44] initially developed EVT to explain personal space violations in interpersonal communication, the theory proved valuable in organizational communication settings. Scholars have found that highly reputable companies face pronounced backlash during crises and other negative events because expectations for behavior are especially high $[46,47]$; that the public views organizations critically when they violate their core ethical values [48]; and that consumers who expect organizations to engage in social advocacy look unfavorably upon companies that remain silent regarding hot-button, sociopolitical issues [49].

EVT seems particularly relevant to legitimacy as one can view legitimacy gaps emerging as a result of expectancy gaps. Recall that legitimacy theory is rooted in the social contract; from that perspective, "when society's expectations are not fulfilled, that is, a company's actual or perceived behavior is not in accordance with social values and norms, a breach of contract exists and a legitimacy gap may develop" [50] (p. 236). Relying on an EVT framework, one would expect pragmatic and moral legitimacy, and thus cognitive legitimacy, to break down when organizations fail to meet expectations for daily operations, economic exchanges, and normative obligations.

\subsection{Signaling Theory}

Importantly, when applied within the overarching legitimacy theory framework, EVT implies that fulfilling or defying behavioral expectations constitutes a communicative act that indicates to stakeholders whether an organization has upheld the social contract and should therefore be conferred legitimacy. Signaling theory serves a key explanatory role here.

Spence [51,52] introduced signaling theory to explain how audiences utilize cues or signals as a tool for evaluating communicator intent. Signaling theory explains various human behaviors within environments of information asymmetries in which a communicator has more detailed information than a receiver, such that a receiver can only rely on incomplete, misleading, and/or imperfect information to assign meaning to communicators' actions $[53,54]$.

Organizations rely on a variety of cues, such as advertising [55-57], warranties [58], service bundling [59], price [60], branding [61,62], and even demarketing [63], to signal the value(s) of a product, service, brand, or organization.

More specifically, PR efforts, including publicity [64-67], social responsibility [68-70], and organizational advocacy [49,71-73], signal to an organization's public its competencies and values, which, when met, can become grounds for conferring legitimacy.

\section{Corporate Social Responsibility as a Legitimizing Activity}

Among these efforts, corporate social responsibility (CSR) is arguably most deeply connected to legitimacy, and similar to legitimacy, CSR has been widely studied and variably defined. In his oft-cited study of CSR's evolution through the 20th century, Carroll [74] quoted more than 30 distinct definitions of the construct. However, reviewing the literature for commonalities allows us to produce a succinct working definition.

\subsection{A Pragmatic or Moral Practice?}

Reflective of the moral and pragmatic elements of legitimacy, CSR balances ethical and economic concerns. Davis's [75] view that "social responsibilities of businessmen need to be commensurate with their social power" (p. 71), which he dubbed the iron law of social responsibility, resonates in the works of later scholars who view organizations as having a moral responsibility for the welfare of communities that provide resources necessary for 
their successes [76-81]. However, early proponents of CSR, particularly Johnson [82] and Steiner [83], were leery of considering CSR a purely normative practice, instead preferring to view initiatives as motivated by enlightened self-interest. Numerous studies have demonstrated a positive link between CSR and organizational reputation, which in turn creates a host of economic benefits for organizations, including increased profit/revenue [84,85], boosts in sales [86,87], greater consumer loyalty $[88,89]$, improved ability to attract investors [90,91], and enhanced employee productivity and retention [92,93].

Embracing both the normative and instrumental aspects, and considering the primacy of the latter in past scholarship, we define CSR as a voluntary action on the part of organizations that address stakeholder needs and wants, with the primary goal of managing reputations to help organizations achieve self-preservation and long-term profitability, while also fulfilling societal expectations to advance the general welfare.

Whether economically or ethically motivated, several scholars argue that CSR serves a legitimizing function [24,25]. Janang, Joseph, and Said [5] explicitly claimed that the "main purpose of firms adopting CSR is because they want to be socially accepted and seen as a legitimate entity by the affected stakeholders" (p. 661). According to Frynas and Stephens [35], stakeholders have come to expect organizations to contribute to general societal and environmental welfare. As such, "businesses are bound by the social contract in which the firms agree to perform various socially desired actions in return for approval of their objectives and other rewards" [2] (p. 353). Ideally, CSR initiatives signal to stakeholders a willingness to take on these obligations, generating social capital for the organization and ensuring "the so-called license to operate" [34] (p. 400).

\subsection{A Substantive or Symbolic Exercise?}

However, a concern long plaguing CSR scholars and managers is whether such initiatives truly address the issues at hand or merely serve as window dressing. That is, are the values that underpin CSR built into the organization's culture, or simply bolted on ad hoc [94,95]? Clarke and Gibson-Sweet [96] argued CSR is best understood as an "ongoing means of reinforcing corporate legitimacy and managing reputation" (p. 6). However, reputation management does not necessarily serve as a guiding ethical principle, potentially limiting the moral legitimacy gained from CSR efforts perceived as more of an image tool than a vehicle for needed change $[76,97,98]$. This concern is particularly important for PR scholars and practitioners. Benn et al.'s [76] survey of CEOs found many felt "the public relations role can, and should, only play a minor role in [CSR] implementation" as that "would prevent critics from rejecting it as a public relations stunt" (p. 417, emphasis original).

As it relates to legitimacy, the question here is whether CSR management and messaging is perceived primarily as a substantive or symbolic response to some stakeholder concern or value $[1,3,7,28,30,99]$. According to Ashforth and Gibbs [28], substantive management "involves real, material change in organizational goals, structures, and processes or socially institutionalized practices" (p. 178); on the other hand, "[r]ather than actually change its ways, the organization might simply portray—or symbolically manage-them so as to appear consistent with social values and expectations" (p. 180, emphasis original).

Substantive responses typically result from coercive isomorphism, in which organizations respond to pressures from stakeholders upon whom they are dependent to meet cultural or societal expectations $[33,100]$. As a result, demand for impactful CSR initiatives can, over time, make such practices a norm [5]. Symbolic responses can vary widely. Organization can (a) deny engaging in unacceptable behaviors, (b) offer excuses or justifications for prior missteps, (c) recast past behaviors more positively, or (d) promote socially acceptable goals publicly while pursuing less accepted goals privately. This final response in particular represents a ceremonial conformity, such that the organization visibly seems in line with accepted behaviors, though significant change never occurs. Perhaps unsurprisingly, managers often prefer symbolic assurances as they require leaner 
resource commitments, whereas organizational stakeholders prefer substantive actions as they generate more meaningful impacts [28].

\section{Communicating Legitimacy through CSR Messaging}

\subsection{Evaluating Pragmatic and Moral Legitimacy through Reputational Effects}

Still, dividing the pragmatic from the moral or the substantive from the symbolic rarely makes for a clean separation. Several mitigating factors are always at play, while others prove more situationally challenging, such as the circumstances facing business during the coronavirus pandemic.

Following Clarke and Gibson-Sweet's [96] argument that CSR helps reinforce legitimacy through improved organizational reputations, it becomes paramount to consider the multifaceted nature of corporate reputation and CSR's role in bolstering both its pragmatic and moral aspects [101,102]. Fombrun, Gardberg, and Sever [101] defined corporate reputation as "a collective assessment of a company's ability to provide valued outcomes to a representative group of stakeholders" (p. 243). In their landmark study, Brown and Dacin [103] distinguished two broad categories of cognitive associations stakeholdersconsumers in particular-hold toward a corporation that affect reputational assessments: "Corporate ability associations are those associations related to the company's expertise in producing and delivering its outputs. Corporate social responsibility associations reflect the organization's status and activities with respect to its perceived societal obligations" (p. 68). These associations roughly track with economic and ethical motives for engaging CSR, as well as respective expectations for pragmatic and moral legitimacy.

A wide array of studies have demonstrated CSR's ability to boost corporate reputation not only in the social responsibility dimension, but also in the corporate ability (CA) dimension, while others have found these associations to be inextricably linked through moderating or mediating effects $[25,69,103-111]$. As such, CSR initiatives likely provide pathways to establishing both pragmatic and moral legitimacy, and evaluating the effects of CSR on different reputational dimensions should indicate exactly how and under what conditions [102].

\subsection{Substantive Responses and Message Informativeness}

The reputational power of a CSR rests in its signaling ability. Several studies have investigated the positive moderating influence of such constructs as honesty, reliability, visibility, clarity, fit, and consistency [58,68,112-118]. As such, to be an effective legitimizing tool, CSR messages must signal substantive commitment to the issue at hand rather than simply symbolic support.

Problematically, however, symbolic responses are effective primarily because they imitate substantive ones. As Aldrich and Fiol [30] argued, organizations that "behave 'as if' the activity were a reality - producing and directing great theater, as it were-may convince others of the tangible reality of the new activity" (p. 651). It would appear, then, that CSR initiatives would more likely be viewed as substantive if messaging about these efforts included details merely symbolic responses could not mimic. Message informativeness proves instructive here.

Because stakeholders are often either unaware of CSR initiatives [119] or have difficulty comprehending CSR communications [68], the informativeness of CSR message content is key. Kim and Ferguson [120] posited that CSR communication should "contain detailed information about a company's CSR activities" (p. 553), which according to Du, et al. [121] includes commitment (how much, long, or consistently a company has supported a social issue), impact (societal or environmental benefits), motives (economic or ethical reasons for supporting the issue), and fit (the logical connection between the issue and the company's business operations).

In this study, we rely primarily on the commitment and impact factors, defining CSR message informativeness as the inclusion of detailed means by which an organization strives to achieve some specified social benefit. While motivation is critical, it can easily 
be communicated symbolically without taking material actions. However, detailed action plans are more substantive in nature. As such, organizations engaging in purely symbolic CSR responses would be reasonably less likely to include these details as the veracity of such claims is easily challenged. Therefore, we posit the following hypothesis:

Hypothesis 1. More informative CSR messages will increase assessments of organizational reputation as related to its (a) treatment of customers, (b) treatment of employees, (c) financial strength and reliability, (d) product and service quality, and (e) social and environmental responsibility.

\subsection{Motivation and Message Sidedness}

Still, whether stakeholders perceive organizational CSR motivations as more economically self-serving or ethically other-serving remains paramount. Message position and composition affects inferred motivations, making message sidedness and important factor. Message sidedness refers to the different perceptions of audiences depending on the message's position: single-/one- or double-/two-sided [122-124]. Messages that present only intrinsic or extrinsic motives (i.e., self-serving or other-serving) are considered onesided, whereas messages that present both intrinsic and extrinsic motives are considered two-sided [124].

Scholars have explored the positive effects of two-sided messages across a variety of contexts, particularly in relation to brand communication and advertising [122,125]. Generally, audiences are more likely to support a two-sided advertisement as it is perceived as more honest and fair compared with a one-sided advertisement [122,126]. Moreover, online blogs [127] and commercial review sites [128] are considered more trustworthy when two-sided messages are employed.

Message sidedness can similarly explain how audiences respond to CSR messages, and how organizations should design and deliver them. Lim, et al. [129] found that when a public is highly involved in a social issue related to a company's CSR practices (i.e., environmental issues), a two-sided CSR message can lead to more positive CSR perceptions than a one-sided message.

However, a double-sided message is not always perceived as well-balanced or trustworthy to its audience [123]. A polarized opinion can reinforce the audience's attitude/opinion when encountering a two-sided message. For example, the audience will selectively perceive information based on their preferred political attitude. People generally feel more comfortable processing information with a familiar topic or tone regardless of message sidedness $[123,130,131]$.

Given the inconclusive findings regarding single- and double-sided messages, we ask the following research question:

Research Question 1. How will single-sided/other-oriented, single-sided/self-oriented, and doublesided/self-other-oriented CSR messages effect organizational reputation assessments related to (a) treatment of customers, (b) treatment of employees, (c) financial strength and reliability, (d) product and service quality, and (e) social and environmental responsibility?

\subsection{Leadership and Isomorphism}

A final variable of interest regards an organization's CSR messaging as it relates to other entities operating in the same market sector, namely whether the proposed initiative is unique. CSR leadership has its benefits. The public perceives organizations breaking new ground as more authentic and internally motivated when they are distinctive among peers in advancing a new initiative [132-134]. Additionally, trailblazers enjoy the advantage of differentiation in the early days of such efforts, setting them apart from more stagnant peers [135].

However, the success of unique CSR initiatives typically means they will not remain unique for long. Suchman [3] described this as the sector-leader's paradox, which occurs 
when others in the industry react to and mimic new and effective strategies, therefore limiting the competitive advantage once offered.

Moreover, from a legitimacy perspective, new entrants into any endeavor face challenges because the public lacks an existing frame through which to interpret new actions [30]. Adhering to tried-and-true standards rather than staking new ground also has its advantages. According to DiMaggio and Powell [100], "the very fact that [legitimacy strategies] are normatively sanctioned increases the likelihood of their adoption" (p. 148). This tendency to copy and benchmark against successful others, particularly during crises, is called mimetic isomorphism $[33,100]$. Organizations often find stakeholders to be more receptive to established and accepted practices as they are already perceived as legitimate.

Suchman [3] described these dual approaches as taking the form of either "popularization (promoting compressibility by explicating new cultural formulations) or standardization (promoting taken-for-grantedness by encouraging isomorphism)" (p. 592, emphasis original). Because both seem viable approaches, we investigate the following research question:

Research Question 2. Will popularization- or standardization-focused CSR messages more strongly affect organizational reputation assessments as related to (a) treatment of customers, (b) treatment of employees, (c) financial strength and reliability, (d) product and service quality and (e) social and environmental responsibility?

\section{Method}

Broadly speaking, this study investigates how CSR message legitimacy affects consumer assessments of organizational reputation. CSR message legitimacy condition varied in several ways. First, we manipulated whether the message focused on stable exchanges for consumers (pragmatic legitimacy), societal and employee welfare (moral legitimacy), or a combination of the two. This was operationalized using either a single-sided, selfinterested message; single-sided, other-interested message; or double-sided, both-oriented message. Second, we manipulated the degree to which the organization sought to establish legitimacy through mere gestures (symbolic management) or concrete action (substantive management). This was operationalized using uninformative and informative message content. Lastly, we manipulated whether a company sought to establish legitimacy through proselytizing a new policy (popularization) or mimicking prominent others in the industry (standardization). This was operationalized as an organization taking a leadership or followership position.

\subsection{Stimuli and Pilot Test}

To increase ecological validity, we used a real-world brand for this study: the United Parcel Service. Interbrand [136] ranked UPS as the 29th best global brand in 2021, and that same year, the Harris Poll [137] ranked UPS 19 on its list of most reputable brands. UPS is thus respected, but not excessively so. Moreover, given the increase in online shopping during the COVID-19 pandemic [138], UPS was likely a visible presence in many Americans' lives, as were its major competitors.

The study relied on a $3 \times 2 \times 2$ experimental survey, which manipulated pragmatic and moral legitimacy using three conditions (self- vs. other- vs. both-oriented messaging); substantive and symbolic management (informative vs. uninformative content); and popularization and standardization approaches (leadership vs. followership). For the stimuli, we drafted email messages regarding UPS's new COVID-19 safety measures, which the company seemingly sent to its major stakeholders (see Appendix A). These stimuli were pilot tested to evaluate the various manipulations. A sample of $N=562$ U.S. adults was recruited from Amazon Mechanical Turk and paid USD 0.10 for participating in the pilot study. The survey was administered through Qualtrics and participants were randomly assigned to one of 12 treatment conditions.

To test the pragmatic/moral/both legitimacy manipulation, participants were asked, "based on what you just read, would you say UPS is most concerned with ... (a) its own interest, (b) the interests of others, or (c) equally concerned with self and others." 
A chi-square crosstabs analysis showed significant differences among the conditions in the expected directions, $\chi^{2}(4)=21.51, p<0.001$. For the popularization/standardization manipulation, participants were asked, "based on what you just read, would you say UPS is ... (a) following other companies on this social issue, or (b) leading other companies on this social issue." Again, a chi-square crosstabs analysis showed significant differences among the conditions in the expected directions, $\chi^{2}(1)=87.99, p<0.001$. Finally, for the substantive/symbolic management condition, participants were asked on a seven-point Likert scale (1: "strongly disagree" to 7: "strongly agree") to answer the following five items based on Kim and Ferguson's [120] definition of informativeness: "(1) it is clear what social issue UPS supports; (2) UPS provided clear details of how it will support this social issue; (3) it is clear why UPS supports this social issue; (4) it is clear how long UPS has supported this issue; (5) it is clear what impacts UPS hopes to make by supporting this issue." Given the strong scale reliability ( $\alpha=0.86)$, the items were combined to create a summative index $(M=5.31, S D=1.07)$. An independent samples t-test showed significant differences across the substantive $(M=5.47)$ and symbolic $(M=5.15)$ conditions, $M_{\text {diff }}=0.32, t(560)=3.59$, $p<0.001$.

\subsection{Procedures and Measures}

For the main study, participants $(N=985)$ were recruited from MTurk and offered USD 0.50 for completing the online survey administered through Qualtrics in October 2020. The initial sample consisted of $N=1008$. Once participants agreed to IRB informed consent, they completed MacKenzie and Lutz's [139] three-item, seven-point semantic differential scale measuring their pre-existing attitude toward UPS, used as a control variable in later analyses $(\alpha=0.78, M=5.77, S D=0.97)$. They were then randomly assigned to one of 12 experimental conditions. Univariate and multivariate outliers were assessed separately within each treatment group. By using boxplots and z-scores, we found each group's outliers in a stimulus reading duration. Because taking an extremely long time for reading a stimulus (e.g., for the raw score of case number $47=660 \mathrm{~s} ; \mathrm{z}=7.64$ ) can reduce the validity of research results, 23 cases in total were removed from the data set [140]. After screening data, the final total was 985, and the reading time for a short stimulus between 219 and 345 words was $M=31.51 \mathrm{~s}$.

After viewing the stimuli, participants were asked to evaluate UPS's corporate reputation. We used the multidimensional measure developed by Walsh and Beatty [102], which included six items measuring customer orientation $(\alpha=0.84, M=5.47, S D=1.21)$; six items measuring good employer $(\alpha=0.87, M=5.50, S D=1.23)$; nine items measuring reliability and financial strength $(\alpha=0.88, M=5.48, S D=1.18)$; five items measuring product and service quality $(\alpha=0.82, M=5.55, S D=1.15)$; and four items measuring social and environmental responsibility $(\alpha=0.80, M=5.41, S D=1.25)$. All were measured using a seven-point Likert scale (1: "strongly disagree" to 7: "strongly agree").

Finally, respondents answered a single seven-point semantic differential item, rating themselves on a scale of liberal (coded -3) to conservative (coded 3), which was utilized as a control variable. The sample leaned slightly conservative $(M=0.99, S D=1.86)$. Demographic information (age, race, gender, and education level) was also collected (see Table 1).

Table 1. Study demographics.

\begin{tabular}{cccc}
\hline & Pilot Test & Main Study & U.S. Population ${ }^{\mathbf{1}}$ \\
\hline Age $(\mathrm{Mdn})$ & 36 & 35 & 38.5 \\
Gender (\% female) & $56.9 \%$ & $40.4 \%$ & $50.8 \%$ \\
Race (\% white) & $63.7 \%$ & $54.2 \%$ & $60.1 \%$ \\
Education & $71.3 \%$ & $87.3 \%$ & $32.1 \%$ \\
\hline (\% bachelor's degree or higher) & & & \\
\hline
\end{tabular}

${ }^{1}$ See U.S. Census Bureau for full population data. 


\section{Results}

Data were analyzed using IBM SPSS, version 27. Hypotheses were tested utilizing a three-way MANCOVA, with the three manipulated conditions (message sidedness, informativeness, and leadership) entered as fixed factors, controls (political ideology and pre-existing attitude) entered as covariates, and the five reputational dimensions set as dependent variables.

We chose this analysis approach for several reasons. First, a covariance analysis allowed us to adjust for potential confounding variables. Given the partisan divide in the U.S. regarding COVID-19-from masking, to vaccination, to the perceived seriousness of the virus-political ideology correlated significantly $(p<0.001)$ with the dependent variables of interest $(0.15<r<0.24)$. Similarly, pre-existing attitudes toward the organization in question similarly correlated to reputational assessments $(0.58<r<0.66, p<0.001)$.

Second, given that experimental conditions were coded nominally, and reputational assessments measured continuously, an analysis of variance was a parsimonious way to address our hypotheses and research questions in comparison with more complex analyses such as PROCESS or structural equation modeling (SEM). Moreover, because we tested the effects of multiple experimental conditions on an array of reputational subdimensions, conducting separate univariate ANOVAs would inflate Type I error; therefore, the multivariate approach was deemed more appropriate [141,142].

Using Pillai's Trace $(V)$, both controls emerged as significant $\left[V_{\text {political }}=0.05, F(5,966)=9.26\right.$, $\left.p<0.001, \eta^{2}=0.05 ; V_{\text {attitude }}=0.45, F(5,966)=156.90, p<0.001, \eta^{2}=0.45\right]$. All main effects for the experimental conditions were nonsignificant $\left[\mathrm{V}_{\text {sidedness }}=0.01, \mathrm{~F}(10,1934)=1.11\right.$, $p=0.35, \eta^{2}=0.01 ; V_{\text {informative }}=0.01, F(5,966)=1.71, p=0.13, \eta^{2}=0.01 ; V_{\text {leader }}=0.004$, $\left.F(5,966)=0.79, p=0.56, \eta^{2}=0.004\right]$, failing to support the overarching assertions made in $\mathrm{H} 1$ and to directly answer our RQs. However, the two-way interaction for leadership $\times$ informativeness $\left[V=0.017, F(5,966)=3.30, p<0.01, \eta^{2}=0.02\right]$ and the three-way interaction for message sidedness $\times$ leadership $\times$ informativeness $[V=0.018, F(10,1934)=1.80$, $\left.p<0.05, \eta^{2}=0.01\right]$ were both significant. As a result, these legitimacy factors affect reputational assessments, just more conditionally than anticipated (see Tables 2 and 3).

Table 2. Follow-up ANOVAs for significant conditions.

\begin{tabular}{|c|c|c|c|c|}
\hline & DV & $F(\mathrm{df})$ & Sig. & $\eta^{2}$ \\
\hline \multirow{5}{*}{ Liberal-Conservative } & Customer Orientation & $17.14(1)$ & $<0.001$ & 0.017 \\
\hline & Good Employer & $16.70(1)$ & $<0.001$ & 0.017 \\
\hline & Reliability and Financial Strength & $8.51(1)$ & 0.004 & 0.009 \\
\hline & Product and Service Quality & $1.80(1)$ & 0.180 & 0.002 \\
\hline & Social and Environmental Responsibility & $29.52(1)$ & $<0.001$ & 0.030 \\
\hline \multirow{5}{*}{ Pre-existing Attitude } & Customer Orientation & $576.74(1)$ & $<0.001$ & 0.373 \\
\hline & Good Employer & $501.42(1)$ & $<0.001$ & 0.341 \\
\hline & Reliability and Financial Strength & $612.58(1)$ & $<.001$ & 0.387 \\
\hline & Product and Service Quality & $698.54(1)$ & $<0.001$ & 0.419 \\
\hline & Social and Environmental Responsibility & $415.13(1)$ & $<0.001$ & 0.300 \\
\hline \multirow{5}{*}{$\begin{array}{l}\text { Leadership } \times \\
\text { Informativeness }\end{array}$} & Customer Orientation & $6.14(1)$ & 0.013 & 0.006 \\
\hline & Good Employer & $7.10(1)$ & 0.008 & 0.007 \\
\hline & Reliability and Financial Strength & $10.05(1)$ & 0.002 & 0.010 \\
\hline & Product and Service Quality & $3.10(1)$ & 0.079 & 0.003 \\
\hline & Social and Environmental Responsibility & $11.57(1)$ & $<0.001$ & 0.012 \\
\hline Leadership $\times$ & Customer Orientation & $3.02(2)$ & 0.049 & 0.006 \\
\hline Informativeness $\times$ & Good Employer & $6.40(2)$ & 0.002 & 0.013 \\
\hline \multirow[t]{3}{*}{ Message Sidedness } & Reliability and Financial Strength & $3.41(2)$ & 0.033 & 0.007 \\
\hline & Product and Service Quality & $3.87(2)$ & 0.021 & 0.008 \\
\hline & Social and Environmental Responsibility & $0.80(2)$ & 0.449 & 0.002 \\
\hline
\end{tabular}


Table 3. Estimates for informativeness $\times$ leadership conditions.

\begin{tabular}{|c|c|c|c|c|}
\hline DV & Informativeness & Leadership & $M$ & $S E$ \\
\hline \multirow[t]{4}{*}{ Customer Orientation } & \multirow[t]{2}{*}{ Symbolic } & Standardization & 5.50 & 0.05 \\
\hline & & Popularization & 5.46 & 0.04 \\
\hline & \multirow[t]{2}{*}{ Substantive } & Standardization & 5.37 & 0.04 \\
\hline & & Popularization & 5.54 & 0.04 \\
\hline \multirow[t]{4}{*}{ Good Employer } & \multirow[t]{2}{*}{ Symbolic } & Standardization & 5.50 & 0.05 \\
\hline & & Popularization & 5.45 & 0.05 \\
\hline & \multirow[t]{2}{*}{ Substantive } & Standardization & 5.43 & 0.05 \\
\hline & & Popularization & 5.63 & 0.05 \\
\hline \multirow[t]{4}{*}{ Reliability and Financial Strength } & \multirow[t]{2}{*}{ Symbolic } & Standardization & 5.54 & 0.04 \\
\hline & & Popularization & 5.45 & 0.04 \\
\hline & \multirow[t]{2}{*}{ Substantive } & Standardization & 5.39 & 0.04 \\
\hline & & Popularization & 5.55 & 0.04 \\
\hline \multirow[t]{4}{*}{ Product and Service Quality } & \multirow[t]{2}{*}{ Symbolic } & Standardization & 5.59 & 0.04 \\
\hline & & Popularization & 5.54 & 0.04 \\
\hline & \multirow[t]{2}{*}{ Substantive } & Standardization & 5.49 & 0.04 \\
\hline & & Popularization & 5.59 & 0.04 \\
\hline \multirow{4}{*}{ Social and Environmental Responsibility } & \multirow[t]{2}{*}{ Symbolic } & Standardization & 5.45 & 0.05 \\
\hline & & Popularization & 5.34 & 0.05 \\
\hline & \multirow[t]{2}{*}{ Substantive } & Standardization & 5.30 & 0.05 \\
\hline & & Popularization & 5.54 & 0.05 \\
\hline
\end{tabular}

Figure 1a-e showcase the two-way interaction of leadership $\times$ informativeness. For each reputational subdimension, the same cross-pattern emerged. When organizations adopted a popularization approach to legitimacy-that is an approach introducing and advocating for a new means of legitimization - stakeholders viewed the organization more positively when the message was informative - that is substantive rather than symbolic in nature. The opposite was true for standardization strategies: relying on isomorphism and following practices of established others resulted in more positive views of the organization when the messages were merely symbolic.

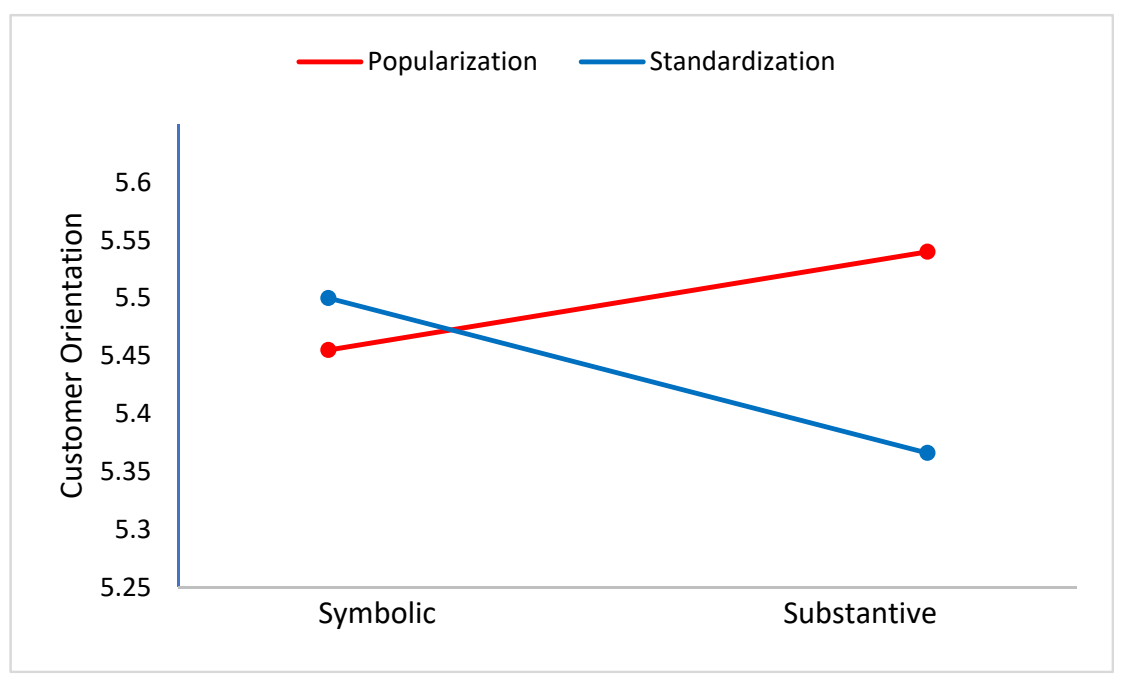

(a)

Figure 1. Cont. 


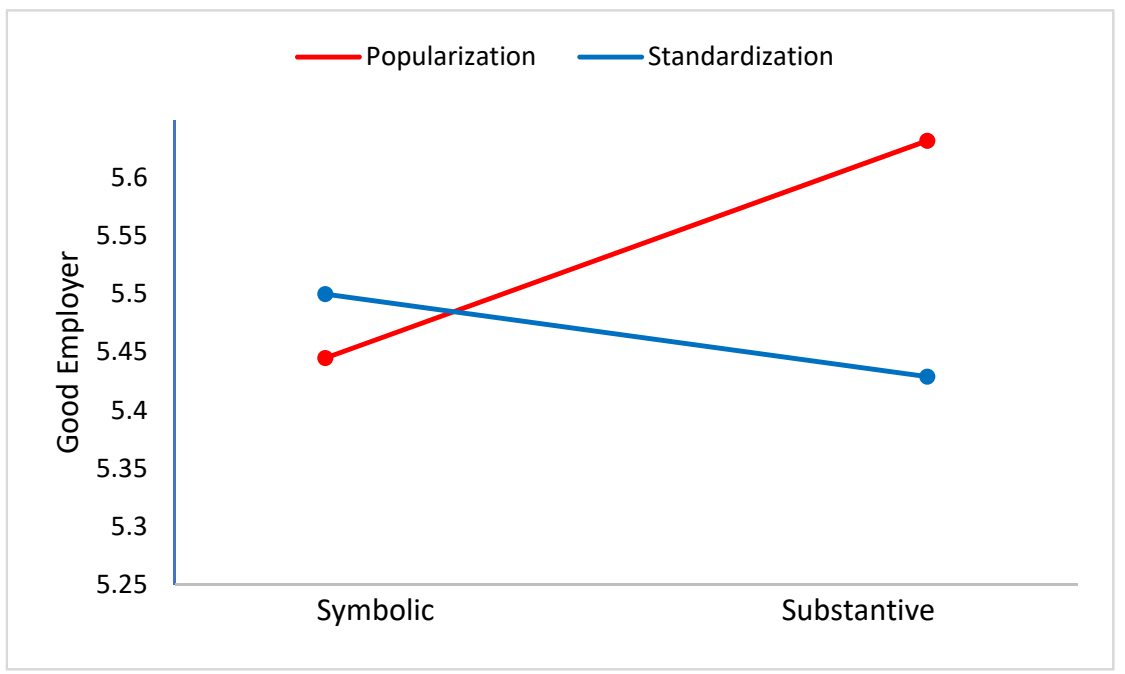

(b)

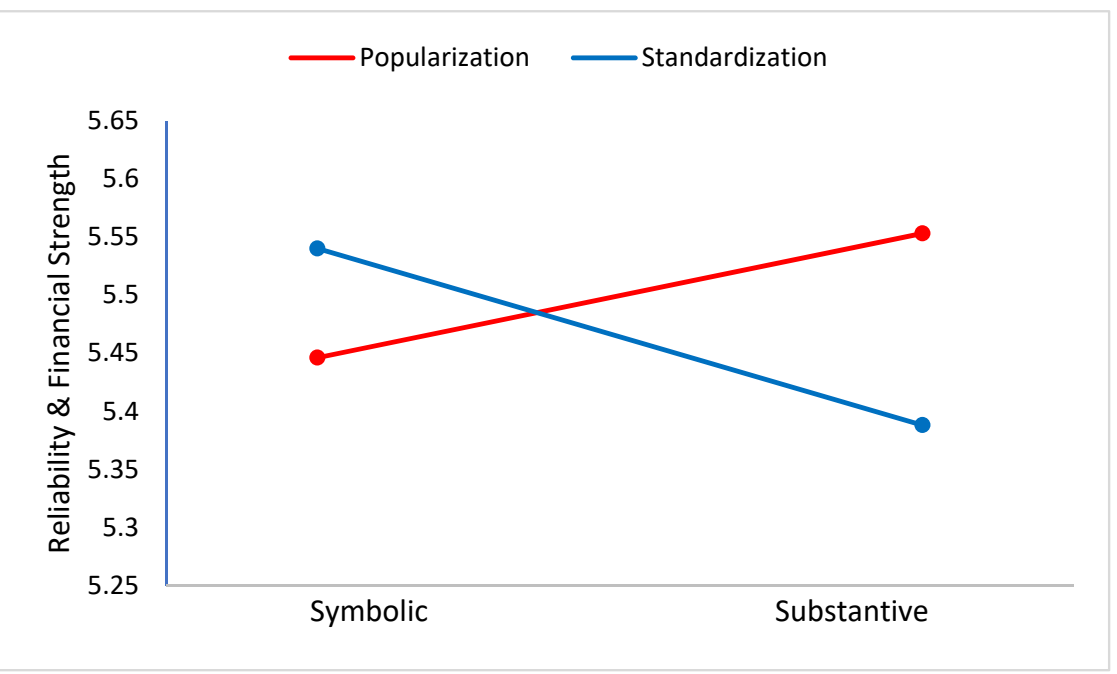

(c)

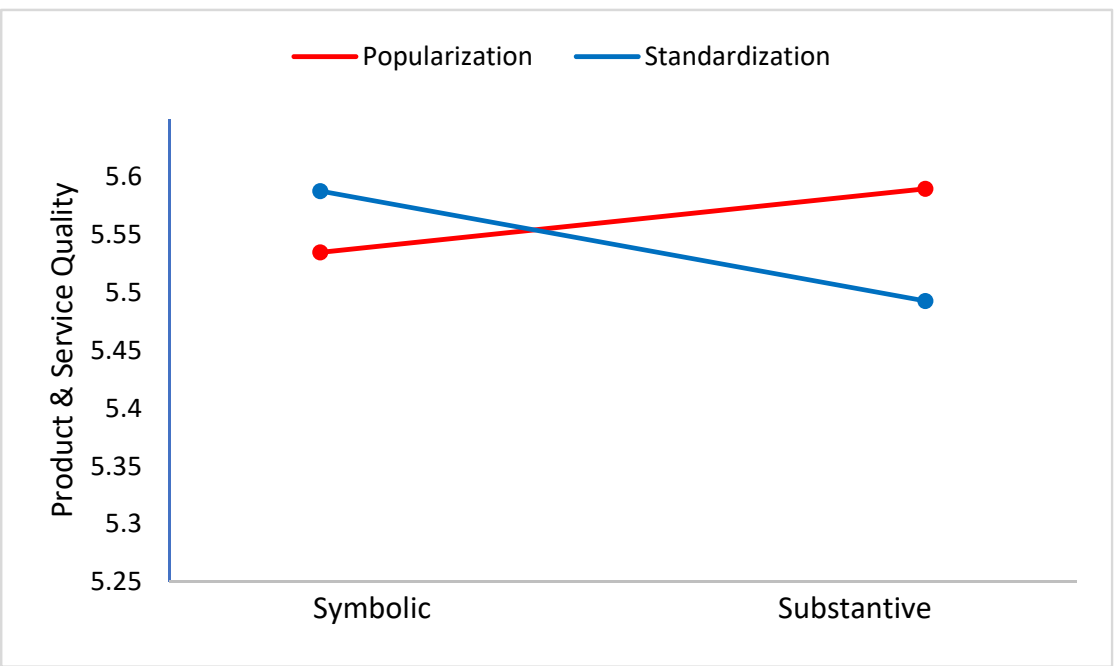

(d)

Figure 1. Cont. 


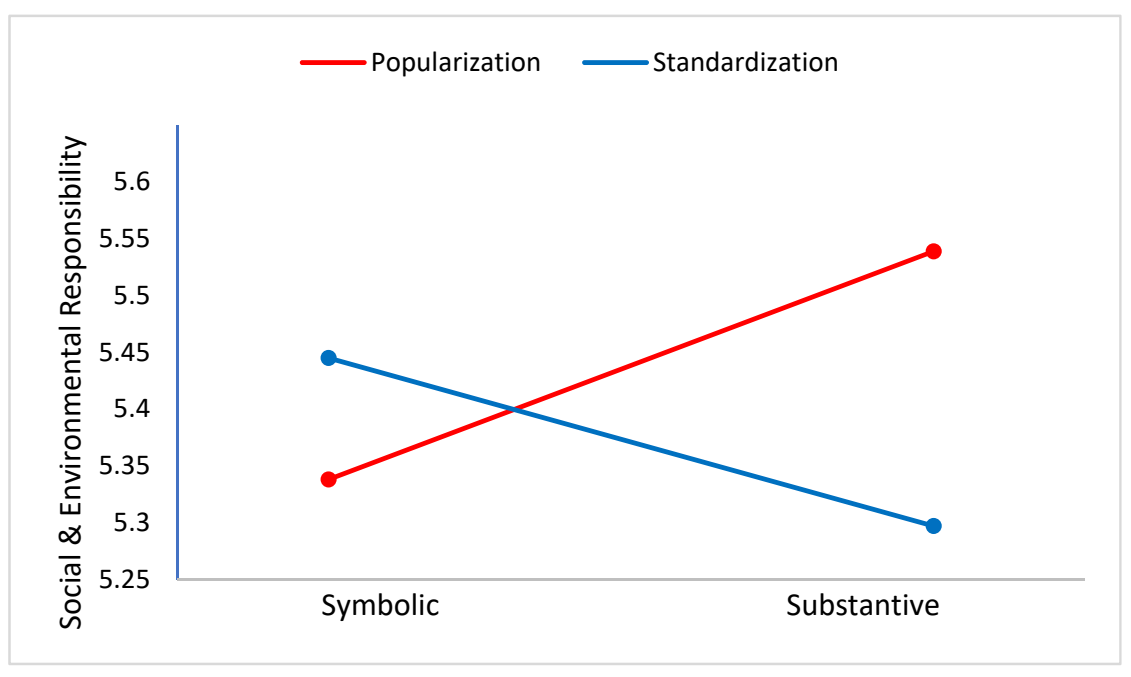

(e)

Figure 1. (a) Two-way interaction on customer orientation. (b) Two-way interaction on good employer. (c) Two-way interaction on reliability and financial strength. (d) Two-way interaction on product and service quality. (e) Two-way interaction on social and environmental responsibility.

The three-way interactions truly show the complex nature of CSR legitimacy, and much greater nuance is required to interpret the results when message sidedness comes into focus (see Figure 2). For double-sided messages - that is when organizations focused on both self- and other-oriented goals (i.e., pragmatic and moral legitimacy) - the same cross pattern emerged for all reputational subdimensions that we saw with the two-way interactions: popularization yielded greater reputational returns when messages were substantive, while standardization approaches were most effective when messages were symbolic. Additionally, this pattern emerged for all conditions predicting social and environmental responsibility reputation.

Regarding reliability and financial strength, this cross pattern again emerged for pragmatic legitimacy strategies. However, when focusing on moral legitimacy, reputational assessments were consistently higher when employing symbolic messaging and relying on popularization strategies.

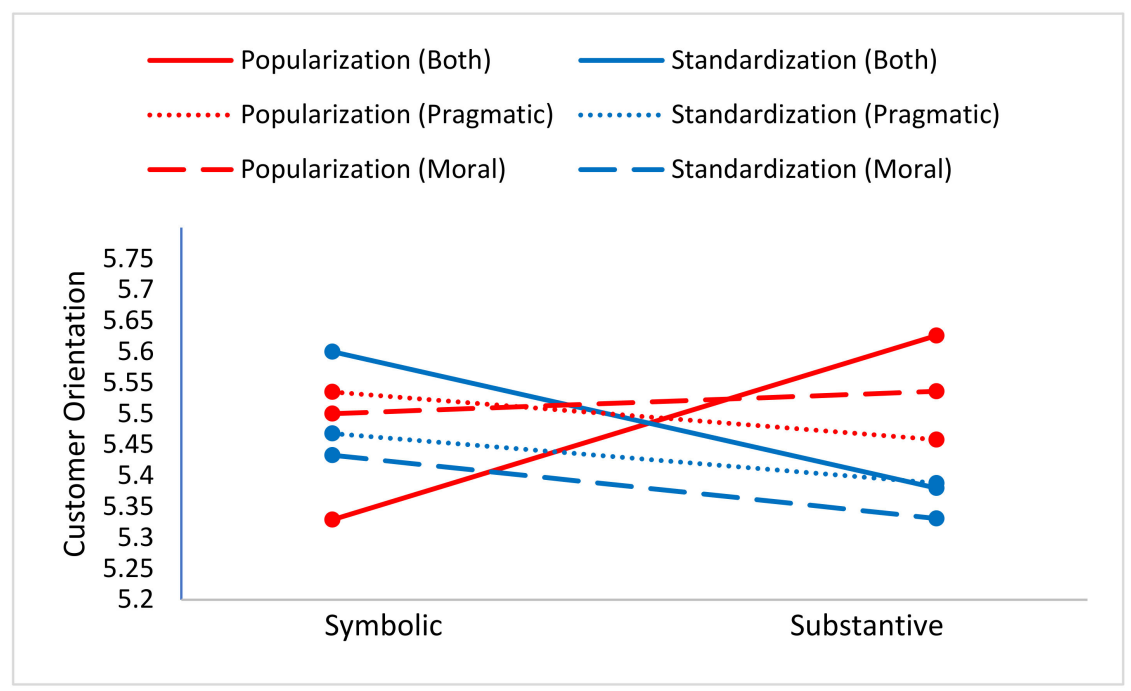

(a)

Figure 2. Cont. 


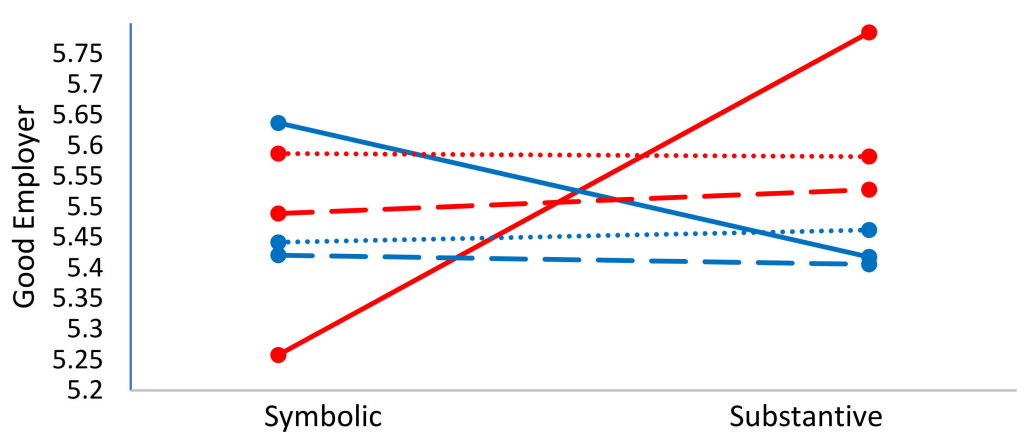

(b)

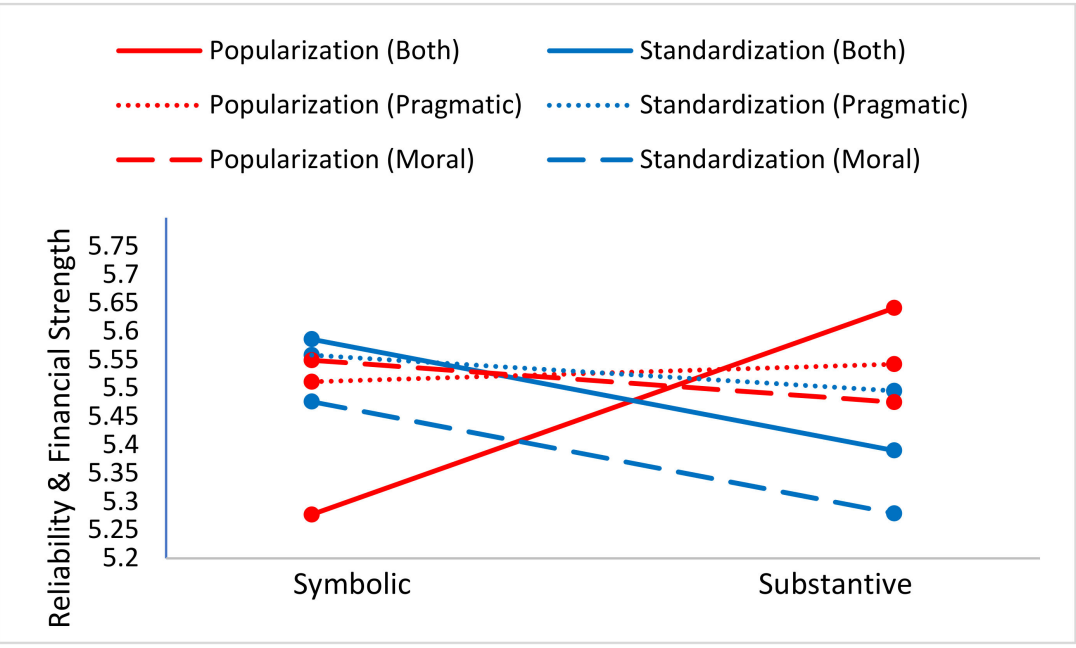

(c)

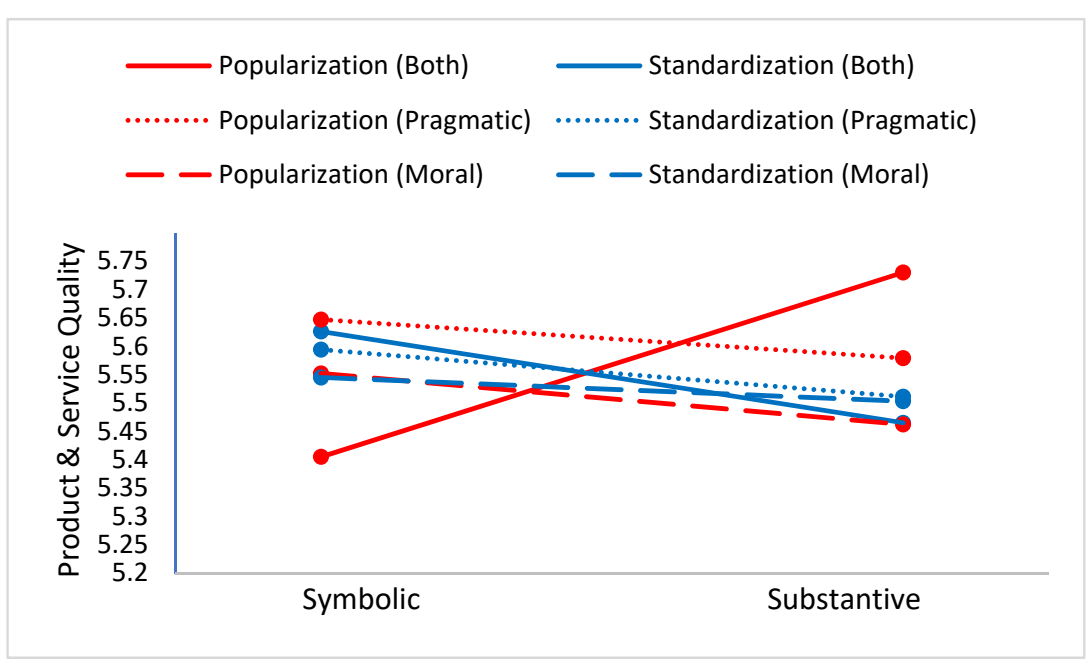

(d)

Figure 2. Cont. 


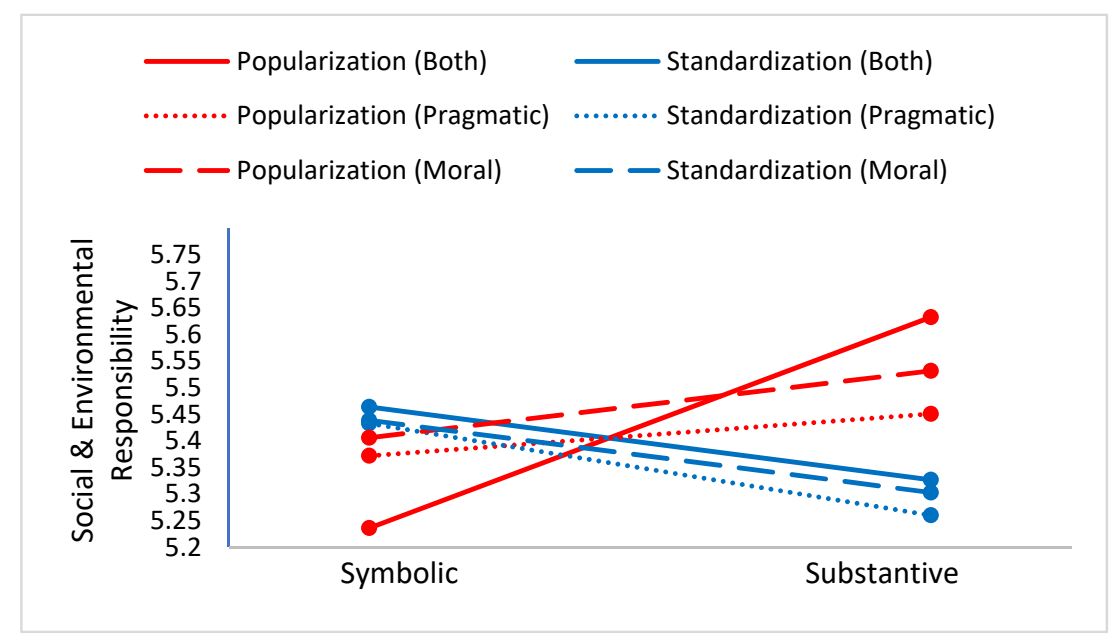

(e)

Figure 2. (a) Three-way interaction on customer orientation. (b) Three-way interaction on good employer. (c) Three-way interaction on reliability and financial strength. (d) Three-way interaction on product and service quality. (e) Three-way interaction on social and environmental responsibility.

Turning to product and service quality reputation, we see that, when highlighting pragmatic legitimacy, utilizing symbolic messaging and popularization strategies resulted in higher reputation assessments. The results for moral legitimacy appear similar, except that a standardization approach appeared slightly more effective when engaging in symbolic messaging.

Reputational assessments for customer orientation and good employer reputations followed similar pathways. Across the board, popularization approaches yielded higher reputational returns. Additionally, when focusing on moral legitimacy, the reputational gap between popularization and standardization approaches was wider when engaging in substantive messaging. The two subdimensions differed, however, in reputational responses for pragmatic legitimization. For both popularization and standardization approaches, customer orientation reputation was higher when utilizing symbolic messaging. Good employer reputation was unique as the gap between popularization and standardization approaches narrowed somewhat: substantive messages were slightly more effective than symbolic messages when engaging in a standardization approach and slightly less effective when engaging in a popularization approach (see Table 4).

Table 4. Interaction effects pattern summary.

\section{Symbolic $\rightarrow$ Substantive \\ Red $=$ Popularization \\ Blue $=$ Standardization}

Legitimacy Type and Reputational Subdimension

\section{All two-way interactions}

All Moral + Pragmatic three-way interactions Moral: Social and Environmental Responsibility Pragmatic: Social and Environmental Responsibility Pragmatic: Reliability and Financial Strength

Moral: Product and Service Quality 
Table 4. Cont.

$\begin{gathered}\text { Symbolic } \rightarrow \text { Substantive } \\ \text { Red }=\text { Popularization } \\ \text { Blue }=\text { Standardization }\end{gathered}$
$\begin{gathered}\text { Legitimacy Type and Reputational Subdimension } \\ \begin{array}{c}\text { Moral: Social and Environmental Responsibility } \\ \text { Pragmatic: Product and Service Quality } \\ \text { Pragmatic: Customer Orientation }\end{array}\end{gathered}$
$\begin{gathered}\text { Moral: Customer Orientation } \\ \text { Moral: Good Employer }\end{gathered}$
Pragmatic: Good Employer

\section{Discussion}

In this study, we experimentally investigated how legitimization strategies embedded in CSR messages related to the COVID-19 pandemic influenced multidimensional stakeholder assessments of reputation. While we found no significant main effects and were thus unable to support our major hypotheses, what we uncovered was a far more nuanced account of how CSR messaging conditionally serves as a legitimization tool to improve organizational reputation.

The two-way interactions of popularization/standardization approaches and substantive/symbolic message characteristics established a clear pattern. Generally, to effectively popularize (i.e., lead) a new legitimacy frontier requires that an organization communicate substantively (i.e., informatively) to establish the value of that new initiative among potentially skeptical audiences. Conversely, standardization approaches that rely on isomorphism are most effective when communicated symbolically, which often relies on vagaries and platitudes with little concrete commitment or impact.

Scholars have long noted the role of isomorphism in promoting the taken-for-granted legitimacy of organizations and their actions, including CSR [3,33]. Isomorphism is a reliable way to maintain the status quo or adjust to changing expectations. Commonly, organizations adopt certain socially responsible behaviors because stakeholders pressure them to (i.e., coercive isomorphism), societal values shift and organizations adapt to meet those demands (i.e., normative isomorphism), or organizations simply copy others in their industry that they perceive as successful (i.e., mimetic isomorphism) [33,100].

Because such positions are firmly established in an existing social contract, a standardization approach for legitimizing such CSR efforts therefore requires little more than a symbolic nod to accepted practices and their generic value. However, introducing and popularizing new modes of legitimization requires substantive explanation to establish the value of such processes. As a result, organizations working to forge new pathways for legitimacy must inform stakeholders of their deep commitment to the approach and convince them of its impact and merit through more informative messaging.

Moreover, three-way interactions reveal that this trend is particularly important for organizations seeking moral legitimacy, especially as it relates to reputations for orienta- 
tion toward customer responsiveness, status as a good employer, and overall social and environmental responsibility. In part, this tendency may have principally emerged in these subdimensions given the nature of our stimuli, which focused a CSR pandemic response message mostly on potential impacts for consumers and employees.

However, success in establishing moral legitimacy using a popularization approach may truly hinge on substantive messaging. As Suchman [3] argued, "at its core, moral legitimacy reflects a prosocial logic that differs fundamentally from narrow self-interest. For this reason, moral claims can be undercut by even an appearance of cynicism" (p. 579). As such, at the moral level, "activities should exemplify responsibility [by] downplaying the role of purely instrumental or consequential concerns" (p. 596). Indeed, Rim and Kim [143] found exactly that, namely that skepticism regarding an organization's altruistic CSR motivations negatively impacts stakeholder attitudes toward the organization, making stakeholders less likely to engage in supportive behaviors. Moreover, communication ethics scholarship has further demonstrated stakeholders' willingness to reward organizations who uphold primary values closely connected to the company's moral character [48], while corporate social advocacy (CSA) research showed that leadership on sociopolitical issues fosters communicated commitment [49]. Collectively, these findings indicate that for ethically ladened issues, the leadership embodied in popularization approaches goes hand in hand with the commitment, fit, impact, and motivation characteristics of substantive responses, both of which appear key in securing moral legitimacy in most circumstances.

Nevertheless, the attribution of CSR motives presents a double-edged sword. While stakeholders expect a degree of altruism in social responsibility efforts, they also understand that corporations chase profits [106]. While consumers often appreciate CSR initiatives, Sen and Bhattacharya [111] found that "if a substantial proportion of a company's potential customers believe that CSR initiatives are typically realized at the expense of CA [corporate ability], the company's CSR efforts may hurt it" (p. 239). To some extent, we see this result here in regard to product and service quality, which participants evaluated more positively when organizations focused on pragmatic rather than moral legitimacy. While consumers want organizations to behave ethically, achieving such moral legitimacy may damage organizations' bottom lines if consumers feel they fall short on delivering quality products and services to achieve that standing. In part this finding supports Burton and Goldsby's [144] assertion that organizations often have little economic incentive to engage in supererogatory behavior once a baseline ethical expectation is met.

Having said that, an all-of-the-above approach to CSR legitimacy seems best. Numerous studies suggest that CSR most often engenders positive responses when it fits logically with both the organization's values and economic business model [145-147]. Such research advises a concurrent quest for pragmatic ends and moral obligations as the most optimal path. Our findings here echo that wisdom. Looking at the means for each reputational subdimension in Table 5 reveals that employing popularization approaches through substantive messaging in simultaneous pursuit of pragmatic and moral legitimacy yielded the highest assessment of reputation across all five subdimensions. For three of the dimensions (customer orientation, good employer, and reliability and financial strength) the standardized, symbolic pursuit of both legitimacy types was the runner-up. For product and service quality, a popularized approach using symbolic messaging to pursue pragmatic legitimacy was the second-best strategy. For social and environmental responsibility, a popularized approach using substantive messaging to pursue moral legitimacy was the second-best strategy. Intuitively, this makes sense as product and service quality closely align with pragmatic legitimacy, whereas the social and environmental responsibility as measured here addresses moral legitimacy concerns.

Still, double-sided messages that emphasize the pragmatic and moral legitimacy of an organization's actions, particularly when that organization substantively commits and works to popularize new initiatives, emerged as the most consistently successful means through which CSR messaging improved reputation. 
Table 5. Estimates for informativeness $\times$ leadership $\times$ message sidedness conditions.

\begin{tabular}{|c|c|c|c|c|c|}
\hline & $\begin{array}{l}\text { Message } \\
\text { Sidedness }\end{array}$ & Informativeness & Leadership & $M$ & $S E$ \\
\hline \multirow[t]{12}{*}{ Customer Orientation } & \multirow[t]{4}{*}{ Pragmatic } & \multirow[t]{2}{*}{ Symbolic } & Standardization & 5.47 & 0.08 \\
\hline & & & Popularization & 5.54 & 0.08 \\
\hline & & \multirow[t]{2}{*}{ Substantive } & Standardization & 5.39 & 0.08 \\
\hline & & & Popularization & 5.46 & 0.08 \\
\hline & \multirow[t]{4}{*}{ Moral } & \multirow[t]{2}{*}{ Symbolic } & Standardization & 5.43 & 0.08 \\
\hline & & & Popularization & 5.50 & 0.08 \\
\hline & & \multirow[t]{2}{*}{ Substantive } & Standardization & 5.33 & 0.08 \\
\hline & & & Popularization & 5.54 & 0.08 \\
\hline & \multirow[t]{4}{*}{ Both } & \multirow[t]{2}{*}{ Symbolic } & Standardization & 5.60 & 0.08 \\
\hline & & & Popularization & 5.33 & 0.08 \\
\hline & & \multirow[t]{2}{*}{ Substantive } & Standardization & 5.38 & 0.08 \\
\hline & & & Popularization & 5.63 & 0.08 \\
\hline \multirow[t]{12}{*}{ Good Employer } & \multirow[t]{4}{*}{ Pragmatic } & \multirow[t]{2}{*}{ Symbolic } & Standardization & 5.44 & 0.09 \\
\hline & & & Popularization & 5.59 & 0.09 \\
\hline & & \multirow{2}{*}{ Substantive } & Standardization & 5.46 & 0.09 \\
\hline & & & Popularization & 5.58 & 0.08 \\
\hline & \multirow[t]{4}{*}{ Moral } & \multirow[t]{2}{*}{ Symbolic } & Standardization & 5.42 & 0.08 \\
\hline & & & Popularization & 5.49 & 0.08 \\
\hline & & \multirow[t]{2}{*}{ Substantive } & Standardization & 5.41 & 0.08 \\
\hline & & & Popularization & 5.53 & 0.08 \\
\hline & \multirow[t]{4}{*}{ Both } & \multirow[t]{2}{*}{ Symbolic } & Standardization & 5.64 & 0.08 \\
\hline & & & Popularization & 5.26 & 0.08 \\
\hline & & \multirow[t]{2}{*}{ Substantive } & Standardization & 5.42 & 0.08 \\
\hline & & & Popularization & 5.79 & 0.08 \\
\hline \multirow{12}{*}{ Reliability and Financial Strength } & \multirow[t]{4}{*}{ Pragmatic } & \multirow[t]{2}{*}{ Symbolic } & Standardization & 5.56 & 0.07 \\
\hline & & & Popularization & 5.51 & 0.07 \\
\hline & & \multirow[t]{2}{*}{ Substantive } & Standardization & 5.50 & 0.07 \\
\hline & & & Popularization & 5.54 & 0.07 \\
\hline & Moral & Symbolic & Standardization & 5.48 & 0.07 \\
\hline & & & Popularization & 5.55 & 0.07 \\
\hline & & Substantive & Standardization & 5.28 & 0.07 \\
\hline & & & Popularization & 5.48 & 0.07 \\
\hline & Both & Symbolic & Standardization & 5.59 & 0.07 \\
\hline & & & Popularization & 5.28 & 0.07 \\
\hline & & Substantive & Standardization & 5.39 & 0.07 \\
\hline & & & Popularization & 5.64 & 0.07 \\
\hline Product and Service Ouality & Pragmatic & Symbolic & Standardization & 5.59 & 0.08 \\
\hline Product and Service Quality & & & Popularization & 5.65 & 0.08 \\
\hline & & Substantive & Standardization & 5.51 & 0.08 \\
\hline & & & Popularization & 5.58 & 0.07 \\
\hline & Moral & Symbolic & Standardization & 5.55 & 0.07 \\
\hline & & & Popularization & 5.55 & 0.07 \\
\hline & & Substantive & Standardization & 5.50 & 0.07 \\
\hline & & & Popularization & 5.46 & 0.07 \\
\hline
\end{tabular}


Table 5. Cont.

\begin{tabular}{|c|c|c|c|c|c|}
\hline & $\begin{array}{l}\text { Message } \\
\text { Sidedness }\end{array}$ & Informativeness & Leadership & $M$ & $S E$ \\
\hline & \multirow[t]{4}{*}{ Both } & \multirow[t]{2}{*}{ Symbolic } & Standardization & 5.63 & 0.07 \\
\hline & & & Popularization & 5.41 & 0.07 \\
\hline & & \multirow[t]{2}{*}{ Substantive } & Standardization & 5.47 & 0.07 \\
\hline & & & Popularization & 5.73 & 0.07 \\
\hline \multirow{12}{*}{$\begin{array}{l}\text { Social and } \\
\text { Environmental Responsibility }\end{array}$} & \multirow[t]{4}{*}{ Pragmatic } & \multirow[t]{2}{*}{ Symbolic } & Standardization & 5.43 & 0.09 \\
\hline & & & Popularization & 5.37 & 0.09 \\
\hline & & \multirow[t]{2}{*}{ Substantive } & Standardization & 5.26 & 0.09 \\
\hline & & & Popularization & 5.45 & 0.09 \\
\hline & \multirow[t]{4}{*}{ Moral } & \multirow[t]{2}{*}{ Symbolic } & Standardization & 5.44 & 0.09 \\
\hline & & & Popularization & 5.41 & 0.09 \\
\hline & & \multirow[t]{2}{*}{ Substantive } & Standardization & 5.30 & 0.09 \\
\hline & & & Popularization & 5.53 & 0.09 \\
\hline & \multirow[t]{4}{*}{ Both } & \multirow[t]{2}{*}{ Symbolic } & Standardization & 5.46 & 0.09 \\
\hline & & & Popularization & 5.24 & 0.09 \\
\hline & & \multirow[t]{2}{*}{ Substantive } & Standardization & 5.33 & 0.09 \\
\hline & & & Popularization & 5.63 & 0.09 \\
\hline
\end{tabular}

\section{Limitations and Future Research}

As with all studies, the current endeavor has its limitations. First, while fairly representative of the U.S. population, the MTurk samples used here were highly educated. Compared with the $32.1 \%$ of U.S. adults who have earned a bachelor's degree or higher, $71.3 \%$ of our pilot sample and $87.3 \%$ of our main sample were so educated. This may in part result from the high unemployment rate for college graduates during the data collection window. According to the Bureau of Labor Statistics, 4.2\% of college graduates were unemployed in October 2020, up from 2.1\% the year prior. Regardless, the education skew of the sample limits the generalizability of findings to some extent, and follow-up studies capturing more participants without college diplomas are needed.

Additionally, the findings here rely on assessments made regarding fictitious CSR actions taken by one company in the midst of a global pandemic. While the use of a real organization increases ecological validity, that is somewhat limited by the fabricated CSR initiative. We chose to craft the messages ourselves to increase experimental control and internal validity, but future research employing actual CSR messaging from an array of companies can better capture the holistic environment in which legitimacy and reputational assessments are made. While one might expect a heightened sense of collective responsibility during a global pandemic and thus a more robust response of CSR efforts aimed at curbing its effects, a number of writers have opined on the persistence of selfish behavior during the pandemic crisis, particularly in the U.S. $[148,149]$. Future studies evaluating CSR legitimacy beyond the COVID-19 sphere can establish either the persistence or boundedness of our findings.

Lastly, this study cast reputation as the dependent variable. Although we measured a variety of subdimensions of the construct that resulted in nuanced findings, it should be noted that reputational gains do not necessarily translate to corresponding behavioral intentions, let alone behavior change itself [150-152]. Additional research is needed to connect CSR legitimization strategies not just to reputational improvements, but proorganizational and prosocial action.

\section{Conclusions}

Despite these limitations, the current study offers valuable insights into the legitimizing role of CSR and how varying message characteristics serve distinct legitimizing 
functions that result in gains across reputational subdimensions. While the discussion section here unpacks many of those key results, for us the most remarkable are the dual importance of pragmatic and moral legitimacy to CSR success, and the value of substantive messaging for organizations to achieve reputational gains. The cultural backdrop of the study only further highlights the significance of these findings.

One could characterize the post-9/11 U.S. as trapped in a "cycle of distrust" [153] (p. 12) - manifesting most thunderingly in the 2020 triple crescendo of racial unrest, election disinformation, and pandemic distress. Americans increasingly distrust one another as well as stalwart institutions [154], making it more difficult for businesses to operate efficiently [155] and instilling in many citizens a sense of helpless in addressing major sociopolitical problems [156].

In the midst of this ennui, organizations face unique challenges. On the one hand, Edelman [153] reports that globally, people tend to trust their employers (77\%) and the business sector generally $(61 \%)$, more so than government $(52 \%)$, media $(50 \%)$, or even NGOs (59\%). On the other hand, people also express a general frustration about the negative externalities of capitalism and a sense that organizations can and should do more to address societal ills [153,157].

As such, it may be that we have entered a new era in which business is no longer just business, but instead something much greater, perhaps something governmental. The forces of globalism have in many instances eroded the power of national institutions and agencies, which may in part explain declining trust in them $[38,41,158]$. In many sectors, governments have pulled back, leaving organizations to handle functions previously managed by the state $[24,39]$, so much so that organizations now play a key role in administering social, civil, and political citizenship rights [37,38].

Viewing CSR and organizational legitimacy through the prism of these tectonic shifts, the key findings of this study appear almost a logical inevitability. Securing pragmatic legitimacy through stable economic exchanges continues to be critical for businesses. However, considering "the role of the corporation in administering citizenship rights for individuals" [37] (p. 173), organizations face increasing pressure to secure the moral legitimacy necessary to address systemic problems of diversity, equity, inclusion, sustainability, and a host of other issues. Given the waning trust in institutions traditionally associated with that citizenship role, it is therefore paramount that organizations speak substantively to these issues to display their commitment and to ensure stakeholders of specific initiatives' impact. CSR, when properly managed, therefore emerges as a viable tool to simultaneously demonstrate economic and ethical commitments and thus garner the pragmatic and moral legitimacy necessary for organizations to succeed.

Author Contributions: Conceptualization, N.B., E.L., S.H.L. and S.-U.Y.; methodology, N.B., E.L. and S.-U.Y.; formal analysis, E.L. and S.-U.Y.; data curation, E.L.; writing-original draft preparation, N.B., E.L. and S.H.L.; writing-review and editing, N.B., E.L., S.H.L. and S.-U.Y.; visualization, N.B.; project administration, N.B. All authors have read and agreed to the published version of the manuscript.

Funding: This research received no external funding.

Institutional Review Board Statement: The study was conducted in accordance with the Declaration of Helsinki, and approved by the Institutional Review Board of Indiana University (protocol code 2005967327, 9 July 2020).

Informed Consent Statement: Informed consent was obtained from all subjects involved in the study.

Data Availability Statement: Data will be made available upon request.

Acknowledgments: We would like to thank the members of the Strategic Communication Research Lab (SCRL) and Indiana University's Media School. Their feedback throughout the various stages of this project proved invaluable, and these pages reflect their collective wisdom.

Conflicts of Interest: The authors declare no conflict of interest. 


\section{Appendix A. Stimuli}

\section{Other-oriented, informative, popularization.}

\section{How UPS is responding to the Coronavirus}

To the UPS family,

I know all of you-our employees, customers, investors, and the communities we serveare struggling with the challenges of the coronavirus pandemic. Your health and safety are most important to us.

\section{Improving Public Health \& Safety}

It all starts with people. In the U.S., over 400,000 dedicated men and women work to deliver nearly 10 million packages and documents every day. We've implemented new, comprehensive measures to ensure our employees' health and safety, as well as that of those they serve.

These measures include:

- $\quad$ Providing all personnel protective masks and gloves

- Retooling distribution centers to ensure 6 feet of social distance between workers

- $\quad$ Allotting 2 weeks of paid sick leave to all employees

- Covering the testing costs for employees displaying coronavirus symptoms

\section{A Leader in Our Industry}

UPS was first in establishing these measures. Upon our urging, other parcel delivery companies such as FedEx, DHL, and the U.S. Postal Service have agreed to adopt our health and safety guidelines as their own.

\section{A Final Word}

It's important to note, however, that we anticipate these measures may reduce our daily volume of deliveries and result in minor delays for customers. We apologize for any inconvenience, but believe that in protecting our employees, we are ultimately protecting our customers as well by minimizing the spread of this awful disease.

At UPS, we strive to do the right thing. Protecting our workers and our customers is simply the right thing to do, and we can't put a price on your health and safety.

Carol Tomé

CEO 


\section{Self-oriented, informative, popularization.}

\section{How UPS is responding to the Coronavirus}

To the UPS family,

I know all of you-our employees, customers, investors, and the communities we serveare struggling with the challenges of the coronavirus pandemic. Right now, we're doing everything we can to stabilize our business.

\section{Boosting Our Revenues}

In the U.S., over 400,000 dedicated men and women work to deliver nearly 10 million packages and documents every day. We've implemented new, comprehensive measures to ensure our stores, distribution centers, and delivery services remain fully staffed and our operations run smoothly-which will increase our profits and stock price.

These measures include:

- $\quad$ Providing all personnel protective masks and gloves

- $\quad$ Retooling distribution centers to ensure 6 feet of social distance between workers

- Allotting 2 weeks of paid sick leave to all employees

- Covering the testing costs for employees displaying coronavirus symptoms

\section{A Leader in Our Industry}

UPS was first in establishing these measures. Upon our urging, other parcel delivery companies such as FedEx, DHL, and the U.S. Postal Service have agreed to adopt our health and safety guidelines as their own.

\section{A Final Word}

It's important to note, however, that we anticipate these measures may reduce our daily volume of deliveries and result in minor delays for customers. We apologize for any inconvenience, but keeping our employees healthy means keeping them on the job, which ultimately makes us better equipped to offer vital services, uninterrupted-in turn keeping us profitable.

At UPS, we strive to serve our customers and shareholders. Protecting our workers means we can keep operations running, which is in the best interest of our business and our bottom line.

Carol Tomé

CEO 


\section{Both-oriented, informative, popularization.}

\section{How UPS is responding to the Coronavirus}

To the UPS family,

I know all of you-our employees, customers, investors, and the communities we serveare struggling with the challenges of the coronavirus pandemic. Your health and safety are important to us, which is why we're doing everything to stay open while also serving you responsibly.

\section{Boosting Our Revenues while Improving Public Health \& Safety}

It all starts with our employees. In the U.S., over 400,000 dedicated men and women work to deliver nearly 10 million packages and documents every day. We've implemented new, comprehensive measures to ensure their health and safety, as well as the health and safety of those they serve. As a result, we feel confident we can keep our stores, distribution centers, and delivery services open for business and fully staffed to meet the needs of our customers.

These measures include:

- $\quad$ Providing all personnel protective masks and gloves

- $\quad$ Retooling distribution centers to ensure 6 feet of social distance between workers

- Allotting 2 weeks of paid sick leave to all employees

- $\quad$ Covering the testing costs for employees displaying coronavirus symptoms

\section{A Leader in Our Industry}

UPS was first in establishing these measures. Upon our urging, other parcel delivery companies such as FedEx, DHL, and the U.S. Postal Service have agreed to adopt our health and safety guidelines as their own.

\section{A Final Word}

It's important to note, however, that we anticipate these measures may reduce our daily volume of deliveries and result in minor delays for customers. We apologize for any inconvenience, but believe that in protecting our employees, we are ultimately protecting our customers as well by minimizing the spread of this awful disease. Moreover, keeping our employees healthy and safe is just good business. It means we're better equipped in the long run to offer vital services to our customers, uninterrupted.

At UPS, we strive to do the right thing. Protecting both our workers and our customers is the right thing to do, and it's also in the best interest of our business and our bottom line.

Carol Tomé

CEO 


\section{Other-oriented, informative, standardization.}

\section{How UPS is responding to the Coronavirus}

To the UPS family,

I know all of you-our employees, customers, investors, and the communities we serveare struggling with the challenges of the coronavirus pandemic. Your health and safety are most important to us.

\section{Improving Public Health \& Safety}

It all starts with people. In the U.S., over 400,000 dedicated men and women work to deliver nearly 10 million packages and documents every day. We've implemented new, comprehensive measures to ensure our employees' health and safety, as well as that of those they serve.

These measures include:

- $\quad$ Providing all personnel protective masks and gloves

- Retooling distribution centers to ensure 6 feet of social distance between workers

- Allotting 2 weeks of paid sick leave to all employees

- Covering the testing costs for employees displaying coronavirus symptoms

\section{Adopting Other Companies' Safety Measures}

UPS is following the guidance issued by other parcel delivery companies such as FedEx, DHL, and the U.S. Postal Service. We have agreed to adopt their measures as our own.

\section{A Final Word}

It's important to note, however, that we anticipate these measures may reduce our daily volume of deliveries and result in minor delays for customers. We apologize for any inconvenience, but believe that in protecting our employees, we are ultimately protecting our customers as well by minimizing the spread of this awful disease.

At UPS, we strive to do the right thing. Protecting our workers and our customers is simply the right thing to do, and we can't put a price on your health and safety.

Carol Tomé

CEO 


\section{Self-oriented, informative, standardization.}

\section{How UPS is responding to the Coronavirus}

To the UPS family,

I know all of you-our employees, customers, investors, and the communities we serveare struggling with the challenges of the coronavirus pandemic. Right now, we're doing everything we can to stabilize our business.

\section{Boosting Our Revenues}

In the U.S., over 400,000 dedicated men and women work to deliver nearly 10 million packages and documents every day. We've implemented new, comprehensive measures to ensure our stores, distribution centers, and delivery services remain fully staffed and our operations run smoothly-which will increase our profits and stock price.

These measures include:

- $\quad$ Providing all personnel protective masks and gloves

- $\quad$ Retooling distribution centers to ensure 6 feet of social distance between workers

- Allotting 2 weeks of paid sick leave to all employees

- Covering the testing costs for employees displaying coronavirus symptoms

\section{Adopting Other Companies' Safety Measures}

UPS is following the guidance issued by other parcel delivery companies such as FedEx, DHL, and the U.S. Postal Service. We have agreed to adopt their measures as our own.

\section{A Final Word}

It's important to note, however, that we anticipate these measures may reduce our daily volume of deliveries and result in minor delays for customers. We apologize for any inconvenience, but keeping our employees healthy means keeping them on the job, which ultimately makes us better equipped to offer vital services, uninterrupted-in turn keeping us profitable.

At UPS, we strive to serve our customers and shareholders. Protecting our workers means we can keep operations running, which is in the best interest of our business and our bottom line.

Carol Tomé

CEO 


\section{Both-oriented, informative, standardization.}

\section{How UPS is responding to the Coronavirus}

To the UPS family,

I know all of you-our employees, customers, investors, and the communities we serveare struggling with the challenges of the coronavirus pandemic. Your health and safety are important to us, which is why we're doing everything to stay open while also serving you responsibly.

\section{Boosting Our Revenues While Improving Public Health \& Safety}

It all starts with our employees. In the U.S., over 400,000 dedicated men and women work to deliver nearly 10 million packages and documents every day. We've implemented new, comprehensive measures to ensure their health and safety, as well as the health and safety of those they serve. As a result, we feel confident we can keep our stores, distribution centers, and delivery services open for business and fully staffed to meet the needs of our customers.

These measures include:

- $\quad$ Providing all personnel protective masks and gloves

- $\quad$ Retooling distribution centers to ensure 6 feet of social distance between workers

- Allotting 2 weeks of paid sick leave to all employees

- Covering the testing costs for employees displaying coronavirus symptoms

\section{Adopting Other Companies' Safety Measures}

UPS is following the guidance issued by other parcel delivery companies such as FedEx, DHL, and the U.S. Postal Service. We have agreed to adopt their measures as our own.

\section{A Final Word}

It's important to note, however, that we anticipate these measures may reduce our daily volume of deliveries and result in minor delays for customers. We apologize for any inconvenience, but believe that in protecting our employees, we are ultimately protecting our customers as well by minimizing the spread of this awful disease. Moreover, keeping our employees healthy and safe is just good business. It means we're better equipped in the long run to offer vital services to our customers, uninterrupted.

At UPS, we strive to do the right thing. Protecting both our workers and our customers is the right thing to do, and it's also in the best interest of our business and our bottom line.

Carol Tomé

CEO 


\section{Other-oriented, uninformative, popularization.}

\section{How UPS is responding to the Coronavirus}

To the UPS family,

I know all of you-our employees, customers, investors, and the communities we serveare struggling with the challenges of the coronavirus pandemic. Your health and safety are most important to us.

\section{Improving Public Health \& Safety}

It all starts with people. In the U.S., over 400,000 dedicated men and women work to deliver nearly 10 million packages and documents every day. We've implemented new, comprehensive measures to ensure our employees' health and safety, as well as that of those they serve.

\section{A Leader in Our Industry}

UPS was first in establishing these measures. Upon our urging, other parcel delivery companies such as FedEx, DHL, and the U.S. Postal Service have agreed to adopt our health and safety guidelines as their own.

\section{A Final Word}

It's important to note, however, that we anticipate these measures may reduce our daily volume of deliveries and result in minor delays for customers. We apologize for any inconvenience, but believe that in protecting our employees, we are ultimately protecting our customers as well by minimizing the spread of this awful disease.

At UPS, we strive to do the right thing. Protecting our workers and our customers is simply the right thing to do, and we can't put a price on your health and safety.

Carol Tomé

CEO 


\section{Self-oriented, uninformative, popularization.}

\section{How UPS is responding to the Coronavirus}

To the UPS family,

I know all of you-our employees, customers, investors, and the communities we serveare struggling with the challenges of the coronavirus pandemic. Right now, we're doing everything we can to stabilize our business.

\section{Boosting Our Revenues}

In the U.S., over 400,000 dedicated men and women work to deliver nearly 10 million packages and documents every day. We've implemented new, comprehensive measures to ensure our stores, distribution centers, and delivery services remain fully staffed and our operations run smoothly-which will increase our profits and stock price.

\section{A Leader in Our Industry}

UPS was first in establishing these measures. Upon our urging, other parcel delivery companies such as FedEx, DHL, and the U.S. Postal Service have agreed to adopt our health and safety guidelines as their own.

\section{A Final Word}

It's important to note, however, that we anticipate these measures may reduce our daily volume of deliveries and result in minor delays for customers. We apologize for any inconvenience, but keeping our employees healthy means keeping them on the job, which ultimately makes us better equipped to offer vital services, uninterrupted-in turn keeping us profitable.

At UPS, we strive to serve our customers and shareholders. Protecting our workers means we can keep operations running, which is in the best interest of our business and our bottom line.

Carol Tomé

CEO 


\section{Both-oriented, uninformative, popularization.}

\section{How UPS is responding to the Coronavirus}

To the UPS family,

I know all of you-our employees, customers, investors, and the communities we serveare struggling with the challenges of the coronavirus pandemic. Your health and safety are important to us, which is why we're doing everything to stay open while also serving you responsibly.

\section{Boosting Our Revenues While Improving Public Health \& Safety}

It all starts with our employees. In the U.S., over 400,000 dedicated men and women work to deliver nearly 10 million packages and documents every day. We've implemented new, comprehensive measures to ensure their health and safety, as well as the health and safety of those they serve. As a result, we feel confident we can keep our stores, distribution centers, and delivery services open for business and fully staffed to meet the needs of our customers.

\section{A Leader in Our Industry}

UPS was first in establishing these measures. Upon our urging, other parcel delivery companies such as FedEx, DHL, and the U.S. Postal Service have agreed to adopt our health and safety guidelines as their own.

\section{A Final Word}

It's important to note, however, that we anticipate these measures may reduce our daily volume of deliveries and result in minor delays for customers. We apologize for any inconvenience, but believe that in protecting our employees, we are ultimately protecting our customers as well by minimizing the spread of this awful disease. Moreover, keeping our employees healthy and safe is just good business. It means we're better equipped in the long run to offer vital services to our customers, uninterrupted.

At UPS, we strive to do the right thing. Protecting both our workers and our customers is the right thing to do, and it's also in the best interest of our business and our bottom line.

Carol Tomé

CEO 


\section{Other-oriented, uninformative, standardization.}

\section{How UPS is responding to the Coronavirus}

To the UPS family,

I know all of you-our employees, customers, investors, and the communities we serveare struggling with the challenges of the coronavirus pandemic. Your health and safety are most important to us.

\section{Improving Public Health \& Safety}

It all starts with people. In the U.S., over 400,000 dedicated men and women work to deliver nearly 10 million packages and documents every day. We've implemented new, comprehensive measures to ensure our employees' health and safety, as well as that of those they serve.

\section{Adopting Other Companies' Safety Measures}

UPS is following the guidance issued by other parcel delivery companies such as FedEx, DHL, and the U.S. Postal Service. We have agreed to adopt their measures as our own.

\section{A Final Word}

It's important to note, however, that we anticipate these measures may reduce our daily volume of deliveries and result in minor delays for customers. We apologize for any inconvenience, but believe that in protecting our employees, we are ultimately protecting our customers as well by minimizing the spread of this awful disease.

At UPS, we strive to do the right thing. Protecting our workers and our customers is simply the right thing to do, and we can't put a price on your health and safety.

Carol Tomé

CEO 


\section{Self-oriented, uninformative, standardization.}

\section{How UPS is responding to the Coronavirus}

To the UPS family,

I know all of you-our employees, customers, investors, and the communities we serveare struggling with the challenges of the coronavirus pandemic. Right now, we're doing everything we can to stabilize our business.

\section{Boosting Our Revenues}

In the U.S., over 400,000 dedicated men and women work to deliver nearly 10 million packages and documents every day. We've implemented new, comprehensive measures to ensure our stores, distribution centers, and delivery services remain fully staffed and our operations run smoothly-which will increase our profits and stock price.

\section{Adopting Other Companies' Safety Measures}

UPS is following the guidance issued by other parcel delivery companies such as FedEx, DHL, and the U.S. Postal Service. We have agreed to adopt their measures as our own.

\section{A Final Word}

It's important to note, however, that we anticipate these measures may reduce our daily volume of deliveries and result in minor delays for customers. We apologize for any inconvenience, but keeping our employees healthy means keeping them on the job, which ultimately makes us better equipped to offer vital services, uninterrupted-in turn keeping us profitable.

At UPS, we strive to serve our customers and shareholders. Protecting our workers means we can keep operations running, which is in the best interest of our business and our bottom line.

Carol Tomé

CEO 


\section{Both-oriented, uninformative, standardization.}

\section{How UPS is responding to the Coronavirus}

To the UPS family,

I know all of you-our employees, customers, investors, and the communities we serveare struggling with the challenges of the coronavirus pandemic. Your health and safety are important to us, which is why we're doing everything to stay open while also serving you responsibly.

\section{Boosting Our Revenues While Improving Public Health \& Safety}

It all starts with our employees. In the U.S., over 400,000 dedicated men and women work to deliver nearly 10 million packages and documents every day. We've implemented new, comprehensive measures to ensure their health and safety, as well as the health and safety of those they serve. As a result, we feel confident we can keep our stores, distribution centers, and delivery services open for business and fully staffed to meet the needs of our customers.

\section{Adopting Other Companies' Safety Measures}

UPS is following the guidance issued by other parcel delivery companies such as FedEx, DHL, and the U.S. Postal Service. We have agreed to adopt their measures as our own.

\section{A Final Word}

It's important to note, however, that we anticipate these measures may reduce our daily volume of deliveries and result in minor delays for customers. We apologize for any inconvenience, but believe that in protecting our employees, we are ultimately protecting our customers as well by minimizing the spread of this awful disease. Moreover, keeping our employees healthy and safe is just good business. It means we're better equipped in the long run to offer vital services to our customers, uninterrupted.

At UPS, we strive to do the right thing. Protecting both our workers and our customers is the right thing to do, and it's also in the best interest of our business and our bottom line.

Carol Tomé

CEO 


\section{References}

1. Dowling, J.; Pfeffer, J. Organizational Legitimacy: Social Values and Organizational Behavior. Pac. Sociol. Rev. 1975, 18, 122-136. [CrossRef]

2. Reverte, C. Determinants of Corporate Social Responsibility Disclosure Ratings by Spanish Listed Firms. J. Bus. Ethics 2009, 88, 351-366. [CrossRef]

3. Suchman, M.C. Managing Legitimacy: Strategic and Institutional Approaches. Acad. Manag. Rev. 1995, 20, 571-610. [CrossRef]

4. Deegan, C. Legitimacy Theory. In Methodological Issues in Accounting Research: Theories, Mehtods and Issues; Hoque, Z., Ed.; Spiramus Press: London, UK, 2006; pp. 161-181.

5. Janang, J.S.; Joseph, C.; Said, R. Corporate Governance and Corporate Social Responsibility Society Disclosure: The Application of Legitimacy Theory. Int. J. Bus. Soc. 2020, 21, 660-678. [CrossRef]

6. Sawyer, K.R.; Johnson, J.; Holub, M. The Necessary Illegitimacy of the Whistleblower. Bus. Prof. Ethics J. 2010, 29 , 85-107. [CrossRef]

7. Hooghiemstra, R. Corporate Communication and Impression Management-New Perspectives Why Companies Engage in Corporate Social Reporting. J. Bus. Ethics 2000, 27, 55-68. [CrossRef]

8. Felix, I.; Mueller, C. US Food Supply Chain: Disruptions and Implications from COVID-19; McKinsey \& Company: New York, NY, USA, 2020

9. McLain, S.; Matthews, C.M.; Paris, C. Everywhere You Look, the Global Supply Chain Is a Mess. The Energy Bulletin. 18 March 2021. Available online: https:/ / daily.energybulletin.org/2021/03/everywhere-you-look-the-global-supply-chain-isa-mess-wsj/ (accessed on 6 January 2022).

10. Shih, W.C. Global Supply Chains in a Post-Pandemic World. In Harvard Business Review; Harvard Business Publishing: Brighton, MA, USA, 2020.

11. U.S. Bureau of Labor Statistics. Supplemental Data Measuring the Effects of the Coronavirus (COVID-19) Pandemic on the Labor Market. 2021. Available online: https://www.bls.gov/cps/effects-of-the-coronavirus-covid-19-pandemic.htm (accessed on 6 January 2022).

12. Barone, E. This Should Be a Boom Time for Restaurants. But Owners—and the Few Workers Remaining-Are Struggling. Time, 29 June 2021.

13. Davidson, P. Great Resignation: The number of people quitting jobs hit an all-time high in November as openings stayed near record. USA Today. 4 January 2022. Available online: https:/ /www.usatoday.com/story/money/2022/01/04/great-resignationnumber-people-quitting-jobs-hit-record/9083256002/ (accessed on 6 January 2022).

14. Kamal, R. Quitting is just half the story: The truth behind the 'Great Resignation'. The Guardian. 4 January 2022. Available online: https:/ / www.theguardian.com/business/2022/jan/04/great-resignation-quitting-us-unemployment-economy (accessed on 6 January 2022).

15. Rosalsky, G. Why are so many Americans quitting their jobs? NPR. 19 October 2021. Available online: https://www.npr.org/ sections / money/2021/10/19/1047032996/why-are-so-many-americans-quitting-their-jobs (accessed on 6 January 2022).

16. Thompson, D. The Great Resignation Is Accelerating. The Atlantic. 15 October 2021. Available online: https://www.theatlantic. com/ideas/archive/2021/10/great-resignation-accelerating/620382/ (accessed on 6 January 2022).

17. Occupational Safety and Health Administration. Protecting Workers: Guidance on Mitigating and Preventing the Spread of COVID-19 in the Workplace; Occupational Safety and Health Administration: Washington, DC, USA, 2021.

18. Hess, A.J. Yes, Employers Can Require Workers Get Vaccinated-And It Might Help Them Attract Top Talent; CNBC: Englewood Cliffs, NJ, USA, 2021.

19. Pollitz, K. What Can Employers Do to Require or Encourage Workers to Get a COVID-19 Vaccine? Kaiser Family Foundation: San Francisco, CA, USA, 2021.

20. Hansen, S. Could Covid-19 Worker Shortages Create A $\$ 15$ Minimum Wage-Even Without a New Law? Forbes. Jersey City, NJ, USA. 15 May 2021. Available online: https:/ / www.forbes.com/sites/sarahhansen/2021/05/15/could-covid-19-workershortages-create-a-15-minimum-wage-even-without-a-new-law/?sh=1611e0c94929 (accessed on 6 January 2022).

21. Giacomini, D.; Martini, M.; Sancino, A.; Zola, P.; Cavenago, D. Corporate social responsibility actions and organizational legitimacy at the peak of COVID-19: A sentiment analysis. Corp. Gov. Int. J. Bus. Soc. 2021, 21, 1043-1058. [CrossRef]

22. Johansen, T.S.; Nielsen, A.E. CSR in corporate self-storying-legitimacy as a question of differentiation and conformity. Corp. Commun. Int. J. 2012, 17, 434-448. [CrossRef]

23. Nielsen, A.E.; Thomsen, C. Reviewing corporate social responsibility communication: A legitimacy perspective. Corp. Commun. Int. J. 2018, 23, 492-511. [CrossRef]

24. Gray, R.; Kouhy, R.; Lavers, S. Corporate social and environmental reporting: A review of the literature and a longitudinal study of UK disclosure. Account. Audit. Account. J. 1995, 8, 47-77. [CrossRef]

25. Perrini, F.; Russo, A.; Tencati, A.; Vurro, C. Deconstructing the Relationship Between Corporate Social and Financial Performance. J. Bus. Ethics 2011, 102, 59-76. [CrossRef]

26. Deegan, C. The legitimising effect of social and environmental disclosures-A theoretical foundation. Account. Audit. Account. J. 2002, 15, 282-311. [CrossRef]

27. Tilling, M.V. Some thoughts on legitimacy theory in social and environmental accounting. Soc. Environ. Account. J. 2004, 24, 3-7. [CrossRef] 
28. Ashforth, B.E.; Gibbs, B.W. The Double-Edge of Organizational Legitimation. Organ. Sci. 1990, 1, 177-194. [CrossRef]

29. Brown, N.; Deegan, C. The public disclosure of environmental performance information-a dual test of media agenda setting theory and legitimacy theory. Account. Bus. Res. 1998, 29, 21-41. [CrossRef]

30. Aldrich, H.E.; Fiol, C.M. Fools Rush in? The Institutional Context of Industry Creation. Acad. Manag. Rev. 1994, 19, 645-670. [CrossRef]

31. Thompson, W.; Browning, N. Writing for Public Relations and Strategic Communication; Cognella: San Diego, CA, USA, 2022.

32. Vaara, E.; Tienar, J. A Discursive Perspective on Legitimation Strategies in Multinational Corporations. Acad. Manag. Rev. 2008, 33, 985-993. [CrossRef]

33. Fernando, S.; Lawrence, S. A Theoretical Framework for CSR Practices: Integrating Legitimacy Theory, Stakeholder Theory and Institutional Theory. J. Theor. Account. Res. 2014, 10, 149-178.

34. Pittroff, E. Whistle-Blowing Systems and Legitimacy Theory: A Study of the Motivation to Implement Whistle-Blowing Systems in German Organizations. J. Bus. Ethics 2013, 124, 399-412. [CrossRef]

35. Frynas, J.G.; Stephens, S. Political Corporate Social Responsibility: Reviewing Theories and Setting New Agendas. Int. J. Manag. Rev. 2014, 17, 483-509. [CrossRef]

36. Kruckeberg, D. The Challenge for Public Relations in the Era of Globalization. Public Relat. Q. 1995, 40, 36-40.

37. Matten, D.; Crane, A. Corporate Citizenship: Toward an Extended Theoretical Conceptualization. Acad. Manag. Rev. 2005, 30, 166-179. [CrossRef]

38. Scherer, A.; Palazzo, G. Toward a political conception of corporate responsibility: Business and society seen from a habermasian perspective. Acad. Manag. Rev. 2007, 32, 1096-1120. [CrossRef]

39. Scherer, A.G.; Palazzo, G. The New Political Role of Business in a Globalized World: A Review of a New Perspective on CSR and its Implications for the Firm, Governance, and Democracy. J. Manag. Stud. 2011, 48, 899-931. [CrossRef]

40. Scherer, A.G.; Palazzo, G.; Baumann, D. Global Rules and Private Actors: Toward a New Role of the Transnational Corporation in Global Governance. Bus. Ethics Q. 2006, 16, 505-532. [CrossRef]

41. Scherer, A.G.; Smid, M. The Downward Spiral and the US Model Business Principles—Why MNEs Should Take Responsibility for the Improvement of World-Wide Social and Environmental Conditions. Manag. Int. Rev. 2000, 40, 351-371.

42. Mio, C.; Fasan, M.; Marcon, C.; Panfilo, S. The predictive ability of legitimacy and agency theory after the implementation of the EU directive on non-financial information. Corp. Soc. Responsib. Environ. Manag. 2020, 27, 2465-2476. [CrossRef]

43. Burgoon, J.K. Interpersonal Expectations, Expectancy Violations, and Emotional Communication. J. Lang. Soc. Psychol. 1993, 12, 30-48. [CrossRef]

44. Burgoon, J.K. A communication model of personal space violations: Explication and an initial test. Hum. Commun. Res. 1978, 4, 129-142. [CrossRef]

45. Burgoon, J.K.; Hale, J.L. Nonverbal expectancy violations: Model elaboration and application to immediacy behaviors. Commun Monogr. 1988, 55, 58-79. [CrossRef]

46. Sohn, Y.J.; Lariscy, R.W. A “Buffer” or “Boomerang?"-The Role of Corporate Reputation in Bad Times. Commun. Res. 2015, 42, 237-259. [CrossRef]

47. Zavyalova, A.; Pfarrer, M.D.; Reger, R.; Hubbard, T. Reputation as a Benefit and a Burden? How Stakeholders' Organizational Identification Affects the Role of Reputation Following a Negative Event. Acad. Manag. J. 2016, 59, 253-276. [CrossRef]

48. Browning, N.; Yang, S.-U.; Park, Y.E.; Lee, E.; Kim, T. Do Ethics Matter? Investigating Donor Responses to Primary and Tertiary Ethical Violations. J. Mass Commun. Q. 2019, 96, 1145-1171. [CrossRef]

49. Browning, N.; Lee, E.; Park, Y.E.; Kim, T.; Collins, R. Muting or Meddling? Advocacy as a Relational Communication Strategy Affecting Organization-Public Relationships and Stakeholder Response. J. Mass Commun. Q. 2020, 97, 1026-1053. [CrossRef]

50. Branco, M.C.; Rodrigues, L. Communication of corporate social responsibility by Portuguese banks: A legitimacy theory perspective. Corp. Commun. Int. J. 2006, 11, 232-248. [CrossRef]

51. Spence, M. Job Market Signaling. Q. J. Econ. 1973, 87, 355-374. [CrossRef]

52. Spence, M. Signaling in Retrospect and the Informational Structure of Markets. Am. Econ. Rev. 2002, 92, 434-459. [CrossRef]

53. Darby, M.; Karni, E. Free Competition and the Optimal Amount of Fraud. J. Law Econ. 1973, 16, 67-88. [CrossRef]

54. Kirmani, A.; Rao, A.R. No Pain, No Gain: A Critical Review of the Literature on Signaling Unobservable Product Quality. J. Mark. 2000, 64, 66-79. [CrossRef]

55. Kihlstrom, R.E.; Riordan, M.H. Advertising as a Signal. J. Polit. Econ. 1984, 92, 427-450. [CrossRef]

56. Kirmani, A. Advertising Repetition as a Signal of Quality: If It's Advertised so Much, Something Must Be Wrong. J. Advert. 1997, 26, 77-86. [CrossRef]

57. Kuksov, D.; Shachar, R.; Wang, K. Advertising and Consumers' Communications. Mark. Sci. 2013, 32, 294-309. [CrossRef]

58. Boulding, W.; Kirmani, A. A consumer-side experimental examination of signaling theory: Do consumers perceive warranties as signals of quality? J. Consum. Res. 1993, 20, 111-123. [CrossRef]

59. Moon, J.; Shugan, S.M. Explaining Bundle-Framing Effects with Signaling Theory. Mark. Sci. 2018, 37, 668-681. [CrossRef]

60. Jiang, B.; Ni, J.; Srinivasan, K. Signaling Through Pricing by Service Providers with Social Preferences. Mark. Sci. 2014, 33, 641-654. [CrossRef]

61. Erdem, T.; Swait, J. Brand Equity as a Signaling Phenomenon. J. Consum. Psychol. 1998, 7, 131-157. [CrossRef] 
62. Rao, A.R.; Qu, L.; Ruekert, R.W. Signaling Unobservable Product Quality through a Brand Ally. J. Mark. Res. 1999, $36,258$. [CrossRef]

63. Miklós-Thal, J.; Zhang, J. (De)marketing to Manage Consumer Quality Inferences. J. Mark. Res. 2013, 50, 55-69. [CrossRef]

64. Gill, R. Why the PR strategy of storytelling improves employee engagement and adds value to CSR: An integrated literature review. Public Relat. Rev. 2015, 41, 662-674. [CrossRef]

65. Kent, M.L.; Taylor, M. From Homo Economicus to Homo dialogicus: Rethinking social media use in CSR communication. Public Relat. Rev. 2016, 42, 60-67. [CrossRef]

66. Kiousis, S.; Popescu, C.; Mitrook, M. Understanding Influence on Corporate Reputation: An Examination of Public Relations Efforts, Media Coverage, Public Opinion, and Financial Performance from an Agenda-Building and Agenda-Setting Perspective. J. Public Relat. Res. 2007, 19, 147-165. [CrossRef]

67. Lee, S.Y.; Riffe, D. Who sets the corporate social responsibility agenda in the news media? Unveiling the agenda-building process of corporations and a monitoring group. Public Relat. Rev. 2017, 43, 293-305. [CrossRef]

68. Browning, N.; Gogo, O.; Kimmel, M. Comprehending CSR messages: Applying the elaboration likelihood model. Corp. Commun. Int. J. 2018, 23, 17-34. [CrossRef]

69. David, P.; Kline, S.; Yang, D. Corporate Social Responsibility Practices, Corporate Identity, and Purchase Intention: A Dual-Process Model. J. Public Relat. Res. 2005, 17, 291-313. [CrossRef]

70. Devin, B.L.; Lane, A. Communicating Engagement in Corporate Social Responsibility: A Meta-Level Construal of Engagement. J. Public Relat. Res. 2014, 26, 436-454. [CrossRef]

71. Dodd, M.D.; Supa, D. Testing the Viability of Corporate Social Advocacy as a Predictor of Purchase Intention. Commun. Res. Rep. 2015, 32, 287-293. [CrossRef]

72. Lim, J.S.; Young, C. Effects of Issue Ownership, Perceived Fit, and Authenticity in Corporate Social Advocacy on Corporate Reputation. Public Relat. Rev. 2021, 47, 102071. [CrossRef]

73. Waymer, D.; Logan, N. Corporate social advocacy as engagement: Nike's social justice communication. Public Relat. Rev. 2020, 47, 102005. [CrossRef]

74. Carroll, A.B. Corporate Social Responsibility: Evolution of a Definitional Construct. Bus. Soc. 1999, 38, 268-295. [CrossRef]

75. Davis, K. Can Business Afford to Ignore Social Responsibilities? Calif. Manag. Rev. 1960, 2, 70-76. [CrossRef]

76. Benn, S.; Todd, L.R.; Pendleton, J. Public Relations Leadership in Corporate Social Responsibility. J. Bus. Ethics 2010, 96, 403-423. [CrossRef]

77. Clark, C. Differences between public relations and corporate social responsibility: An analysis. Public Relat. Rev. 2000, 26, 363-380. [CrossRef]

78. Coombs, W.T.; Holladay, S.J. Managing Corporate Social Responsibility: A Communication Approach; John Wiley \& Sons, Inc.: Chichester, UK, 2012.

79. Hartman, L.P.; Rubin, R.; Dhanda, K.K. The Communication of Corporate Social Responsibility: United States and European Union Multinational Corporations. J. Bus. Ethics 2007, 74, 373-389. [CrossRef]

80. Jin, K.G.; Drozdenko, R.G. Relationships among Perceived Organizational Core Values, Corporate Social Responsibility, Ethics, and Organizational Performance Outcomes: An Empirical Study of Information Technology Professionals. J. Bus. Ethics 2009, 92, 341-359. [CrossRef]

81. Post, J.E.; Frederick, W.C.; Lawrence, A.T.; Weber, J. Business and Society: Corporate Strategy, Public Policy, and Ethics, 8th ed.; McGraw-Hill: New York, NY, USA, 1996.

82. Johnson, H.L. Business in Contemporary Society: Framework and Issues; Wadsworth: Belmont, CA, USA, 1971.

83. Steiner, G.A. Business and Society; Random House: New York, NY, USA, 1971.

84. Abratt, R.; Kleyn, N. Corporate identity, corporate branding and corporate reputations: Reconciliation and integration. Eur. J. Mark. 2012, 46, 1048-1063. [CrossRef]

85. Demetriou, M.; Papasolomou, I.; Vrontis, D. Cause-related marketing: Building the corporate image while supporting worthwhile causes. J. Brand Manag. 2009, 17, 266-278. [CrossRef]

86. Lyon, L.; Cameron, G.T. A Relational Approach Examining the Interplay of Prior Reputation and Immediate Response to a Crisis. J. Public Relat. Res. 2004, 16, 213-241. [CrossRef]

87. Orlitzky, M. Corporate Social Performance and Financial Performance: A Research Synthesis. In The Oxford Handbook of Corporate Social Responsibility; Crane, A., Matten, D., McWilliams, A., Moon, J., Siegel, D., Eds.; Oxford University Press: New York, NY, USA, 2008; pp. 113-134.

88. Luo, X.; Bhattacharya, C.B. The Debate over Doing Good: Corporate Social Performance, Strategic Marketing Levers, and Firm-Idiosyncratic Risk. J. Mark. 2009, 73, 198-213. [CrossRef]

89. Peloza, J.; Shang, J. How can corporate social responsibility activities create value for stakeholders? A systematic review. J. Acad. Mark. Sci. 2010, 39, 117-135. [CrossRef]

90. McWilliams, A.; Siegel, D. Creating and capturing value: Strategic corporate social responsibility, resource based theory and sustainable competitive advantage. J. Manag. 2011, 37, 1480-1495. [CrossRef]

91. Melewar, T. Determinants of the corporate identity construct: A review of the literature. J. Mark. Commun. 2003, 9, 195-220. [CrossRef] 
92. Distaso, M.W. The Annual Earnings Press Release's Dual Role: An Examination of Relationships with Local and National Media Coverage and Reputation. J. Public Relat. Res. 2012, 24, 123-143. [CrossRef]

93. Murillo, D.; Lozano, J.M. SMEs and CSR: An Approach to CSR in their Own Words. J. Bus. Ethics 2006, 67, 227-240. [CrossRef]

94. Dowling, G.; Moran, P. Corporate Reputations: Built in or Bolted on? Calif. Manag. Rev. 2012, 54, 25-42. [CrossRef]

95. Mazutis, D.D.; Slawinski, N. Reconnecting Business and Society: Perceptions of Authenticity in Corporate Social Responsibility. J. Bus. Ethics 2014, 131, 137-150. [CrossRef]

96. Clarke, J.; Gibson-Sweet, M. The use of corporate social disclosures in the management of reputation and legitimacy: A cross sectoral analysis of UK Top 100 Companies. Bus. Ethics A Eur. Rev. 1999, 8, 5-13. [CrossRef]

97. L'Etang, J. The myth of the "ethical guardian": An examination of its origins, potency and illusions. J. Commun. Manag. 2004, 8, 53-67. [CrossRef]

98. Waldman, D.A.; Siegel, D.S.; Stahl, G.K. Defining the Socially Responsible Leader: Revisiting Issues in Responsible Leadership. J. Leadersh. Organ. Stud. 2020, 27, 5-20. [CrossRef]

99. Deephouse, D.L.; Carter, S.M. An Examination of Differences Between Organizational Legitimacy and Organizational Reputation. J. Manag. Stud. 2005, 42, 329-360. [CrossRef]

100. DiMaggio, P.J.; Powell, W.W. The Iron Cage Revisited: Institutional Isomorphism and Collective Rationality in Organizational Fields. Am. Sociol. Rev. 1983, 48, 147. [CrossRef]

101. Fombrun, C.J.; A Gardberg, N.; Sever, J.M. The Reputation QuotientSM: A multi-stakeholder measure of corporate reputation. J. Brand Manag. 2000, 7, 241-255. [CrossRef]

102. Walsh, G.; Beatty, S.E. Customer-based corporate reputation of a service firm: Scale development and validation. J. Acad. Mark. Sci. 2007, 35, 127-143. [CrossRef]

103. Brown, T.J.; Dacin, P.A. The Company and the Product: Corporate Associations and Consumer Product Responses. J. Mark. 1997, 61, 68. [CrossRef]

104. Brammer, S.; He, H.; Mellahi, K. Corporate Social Responsibility, Employee Organizational Identification, and Creative Effort: The Moderating Impact of Corporate Ability. Group Organ. Manag. 2014, 40, 323-352. [CrossRef]

105. Du, S.; Bhattacharya, C.; Sen, S. Reaping relational rewards from corporate social responsibility: The role of competitive positioning. Int. J. Res. Mark. 2007, 24, 224-241. [CrossRef]

106. Gupta, S.; Pirsch, J. The company-cause-customer fit decision in cause-related marketing. J. Consum. Mark. 2006, 23, 314-326. [CrossRef]

107. Kim, S. Transferring Effects of CSR Strategy on Consumer Responses: The Synergistic Model of Corporate Communication Strategy. J. Public Relat. Res. 2011, 23, 218-241. [CrossRef]

108. Luo, X.; Bhattacharya, C. Corporate Social Responsibility, Customer Satisfaction, and Market Value. J. Mark. 2006, 70, 1-18. [CrossRef]

109. Marín, L.; Cuestas, P.J.; Román, S. Determinants of Consumer Attributions of Corporate Social Responsibility. J. Bus. Ethics 2015 138, 247-260. [CrossRef]

110. Park, H.; Kim, S.-Y. A moderated mediation model of corporate social responsibility. J. Commun. Manag. 2015, 19, 306-323. [CrossRef]

111. Sen, S.; Bhattacharya, C. Does Doing Good Always Lead to Doing Better? Consumer Reactions to Corporate Social Responsibility. J. Mark. Res. 2001, 38, 225-243. [CrossRef]

112. Arthurs, J.D.; Busenitz, L.W.; Hoskisson, R.E.; Johnson, R.A. Signaling and initial public offerings: The use and impact of the lockup period. J. Bus. Ventur. 2009, 24, 360-372. [CrossRef]

113. Busenitz, L.W.; Fiet, J.O.; Moesel, D.D. Signaling in Venture Capitalist-New Venture Team Funding Decisions: Does it Indicate Long-Term Venture Outcomes? Entrep. Theory Pract. 2005, 29, 1-12. [CrossRef]

114. Chung, W.; Kalnins, A. Agglomeration effects and performance: A test of the Texas lodging industry. Strat. Manag. J. 2001, 22, 969-988. [CrossRef]

115. Lampel, J.; Shamsie, J. Critical Push: Strategies for Creating Momentum in the Motion Picture Industry. J. Manag. 2000, 26, 233-257. [CrossRef]

116. Ndofor, H.A.; Levitas, E. Signaling the Strategic Value of Knowledge. J. Manag. 2004, 30, 685-702. [CrossRef]

117. Ramaswami, A.; Dreher, G.F.; Bretz, R.; Wiethoff, C. Gender, mentoring, and career success: The importance of organizational context. Pers. Psychol. 2010, 63, 385-405. [CrossRef]

118. Zhang, Y.; Wiersema, M.F. Stock market reaction to CEO certification: The signaling role of CEO background. Strat. Manag. J. 2009, 30, 693-710. [CrossRef]

119. Pomering, A.; Dolnicar, S. Assessing the Prerequisite of Successful CSR Implementation: Are Consumers Aware of CSR Initiatives? J. Bus. Ethics 2009, 85, 285-301. [CrossRef]

120. Kim, S.; Ferguson, M.A.T. Dimensions of effective CSR communication based on public expectations. J. Mark. Commun. 2016, 24, 549-567. [CrossRef]

121. Du, S.; Bhattacharya, C.; Sen, S. Maximizing Business Returns to Corporate Social Responsibility (CSR): The Role of CSR Communication. Int. J. Manag. Rev. 2010, 12, 8-19. [CrossRef]

122. Eisend, M. Understanding two-sided persuasion: An empirical assessment of theoretical approaches. Psychol. Mark. 2007, 24, 615-640. [CrossRef] 
123. Flanagin, A.J.; Winter, S.; Metzger, M.J. Making sense of credibility in complex information environments: The role of message sidedness, information source, and thinking styles in credibility evaluation online. Inf. Commun. Soc. 2018, 23, 1038-1056. [CrossRef]

124. Rim, H.; Song, D. "How Negative Becomes Less Negative": Understanding the Effects of Comment Valence and Response Sidedness in Social Media. J. Commun. 2016, 66, 475-495. [CrossRef]

125. Pechmann, C. Predicting when Two-Sided Ads will be More Effective than One-Sided Ads: The Role of Correlational and Correspondent Inferences. J. Mark. Res. 1992, 29, 441-453. [CrossRef]

126. Allen, M. Meta-analysis comparing the persuasiveness of one-sided and two-sided messages. West. J. Speech Commun. 1991, 55, 390-404. [CrossRef]

127. Winter, S.; Krämer, N.C. Selecting Science Information in Web 2.0: How Source Cues, Message Sidedness, and Need for Cognition Influence Users' Exposure to Blog Posts. J. Comput. Commun. 2012, 18, 80-96. [CrossRef]

128. Jensen, M.L.; Averbeck, J.M.; Zhang, Z.; Wright, K.B. Credibility of Anonymous Online Product Reviews: A Language Expectancy Perspective. J. Manag. Inf. Syst. 2013, 30, 293-324. [CrossRef]

129. Lim, J.S.; Lin, S.Y.; Ferguson, M.A.; Kiousis, S. The Effect of Message Sidedness on CSR Perceptions and Company Evaluations; International Communication Association: Dresden, Germany, 2006.

130. Schwind, C.; Buder, J. Reducing confirmation bias and evaluation bias: When are preference-inconsistent recommendations effective-and when not? Comput. Hum. Behav. 2012, 28, 2280-2290. [CrossRef]

131. Westerwick, A.; Johnson, B.; Knobloch-Westerwick, S. Confirmation biases in selective exposure to political online information: Source bias vs. content bias. Commun. Monogr. 2017, 84, 343-364. [CrossRef]

132. De Ruyter, K.; Moorman, L.; Lemmink, J. Antecedents of Commitment and Trust in Customer-Supplier Relationships in High Technology Markets. Ind. Mark. Manag. 2001, 30, 271-286. [CrossRef]

133. McShane, L.; Cunningham, P. To Thine Own Self Be True? Employees' Judgments of the Authenticity of Their Organization's Corporate Social Responsibility Program. J. Bus. Ethics 2011, 108, 81-100. [CrossRef]

134. Moulard, J.G.; Raggio, R.D.; Folse, J.A.G. Brand Authenticity: Testing the Antecedents and Outcomes of Brand Management's Passion for its Products. Psychol. Mark. 2016, 33, 421-436. [CrossRef]

135. Blomgren, A. Does corporate social responsibility influence profit margins? a case study of executive perceptions. Corp. Soc. Responsib. Environ. Manag. 2010, 18, 263-274. [CrossRef]

136. Interbrand. Best Global Brands. Available online: https://interbrand.com/thinking/best-global-brands-2021-download/ (accessed on 6 January 2022).

137. Harris Poll. Corporate Reputation Rankins. Available online: https://theharrispoll.com/axios-harrispoll-100/ (accessed on 6 January 2022).

138. Boudreau, C. Shopping online surged during Covid. Now the environmental costs are becoming clearer. Politico. 2021. Available online: https:/ / www.politico.com/news/2021/11/18/covid-retail-e-commerce-environment-522786 (accessed on 6 January 2022).

139. MacKenzie, S.B.; Lutz, R.J. An Empirical Examination of the Structural Antecedents of Attitude toward the Ad in an Advertising Pretesting Context. J. Mark. 1989, 53, 48. [CrossRef]

140. Tabachnick, B.G.; Fidell, L.S. Using Multivariate Statistics, 6th ed.; Pearson: New York, NY, USA, 2013.

141. Green, S.B.; Salkind, N.J. Using SPSS for Windows and Macintosh: Analysing and Understanding Data, 7th ed.; Pearson: Upper Sadle River, NJ, USA, 2014.

142. Hair, J.F., Jr.; Black, W.C.; Babin, B.J.; Anderson, R.E. Multivariate Data Analysis, 7th ed.; Prentice Hall: Upper Saddle River, NJ, USA, 2010

143. Rim, H.; Kim, S. Dimensions of corporate social responsibility (CSR) skepticism and their impacts on public evaluations toward CSR. J. Public Relat. Res. 2016, 28, 248-267. [CrossRef]

144. Burton, B.K.; Goldsby, M.G. The Moral Floor: A Philosophical Examination of the Connection Between Ethics and Business. J. Bus. Ethics 2009, 91, 145-154. [CrossRef]

145. Go, E.; Bortree, D.S. What and How to Communicate CSR? The Role of CSR fit, Modality Interactivity, and Message Interactivity on Social Networking Sites. J. Promot. Manag. 2017, 23, 727-747. [CrossRef]

146. Moreno, F.; Kang, J. How to alleviate consumer skepticism concerning corporate responsibility: The role of content and delivery in CSR communications. Corp. Soc. Responsib. Environ. Manag. 2020, 27, 2477-2490. [CrossRef]

147. Villagra, N.; Cárdaba, M.A.M.; Ruiz San Román, J. Communicating Corporate Social Responsibility: Re-assessment of classical theories about fit between CSR actions and corporate activities. Commun. Soc. 2016, 29, 133-146. [CrossRef]

148. Ollove, M. How miscommunication and selfishness hampered America's COVID-19 response. USA Today; McLean, VA, USA, 20 August 2020. Available online: https://www.usatoday.com/story/news/nation/2020/08/20/us-covid-19-response-howmiscommunication-selfishness-played-role/5610047002/ (accessed on 6 January 2022).

149. Sachs, J. The Real Reason This Pandemic Is the Deadliest to Ever Hit the US; CNN: Atlanta, GA, USA, 2021.

150. Auger, P.; DeVinney, T.M. Do What Consumers Say Matter? The Misalignment of Preferences with Unconstrained Ethical Intentions. J. Bus. Ethics 2007, 76, 361-383. [CrossRef]

151. Boulstridge, E.; Carrigan, M. Do consumers really care about corporate responsibility? Highlighting the attitude-behaviour gap. J. Commun. Manag. 2000, 4, 355-368. [CrossRef] 
152. Davidson, D.K. On Corporate Reputation: A Reply to Dobson. Bus. Soc. 1990, 29, 39-41. [CrossRef]

153. Edelman. Edelman Trust Barometer. 2022. Available online: https://www.edelman.com/trust/2022-trust-barometer (accessed on 6 January 2022).

154. Brooks, D. America is Having a Moral Convulsion. The Atlantic. 5 October 2020. Available online: https:/ / www.theatlantic.com/ ideas/archive/2020/10/collapsing-levels-trust-are-devastating-america/616581/ (accessed on 6 January 2022).

155. Useem, J. The End of Trust. The Atlantic. 24 November 2021. Available online: https://www.theatlantic.com/magazine/archive/ 2021/12/trust-recession-economy/620522/ (accessed on 6 January 2022).

156. Rainie, L.; Keeter, S.; Page, D. Trust and Distrust in America; Pew Research Center: Washington, DC, USA, 2019.

157. Edelman. Brands Take a Stand; Edelman: Chicago, IL, USA, 2 October 2018; Available online: https://www.edelman.com/earnedbrand (accessed on 6 January 2022).

158. Young, I.M. Responsibility and Global Labor Justice. J. Polit. Philos. 2004, 12, 365-388. [CrossRef] 